Florida International University FIU Digital Commons

\title{
Environmental stewardship and the fate of the Brazilian Amazon : a case study of the Madeira Complex
}

\author{
Karyna Do Monte \\ Florida International University
}

DOI: $10.25148 /$ etd.FI15101204

Follow this and additional works at: https://digitalcommons.fiu.edu/etd

Part of the Latin American Languages and Societies Commons, and the Religion Commons

\section{Recommended Citation}

Do Monte, Karyna, "Environmental stewardship and the fate of the Brazilian Amazon : a case study of the Madeira Complex" (2009). FIU Electronic Theses and Dissertations. 3067.

https://digitalcommons.fiu.edu/etd/3067 
FLORIDA INTERNATIONAL UNIVERSITY

Miami, Florida

ENVIRONMENTAL STEWARDSHIP AND THE FATE OF THE BRAZILIAN AMAZON: A CASE STUDY OF THE MADEIRA COMPLEX

A thesis submitted in partial fulfillment of the

requirements for the degree of

MASTER OF ARTS

in

RELIGIOUS STUDIES

by

Karyna Do Monte

2009 
To: Dean Kenneth Furton

College of Arts and Sciences

This thesis, written by Karyna Do Monte, and entitled Environmental Stewardship and the Fate of the Brazilian Amazon: A Case Study of the Madeira Complex, having been approved in respect to style and intellectual content, is referred to you for judgment.

We have read this thesis and recommend that it be approved.

Christine E. Gudorf

Oren B. Stier

Whitney Bauman, Major Professor

Date of Defense: March, 26, 2009

The thesis of Karyna Do Monte is approved.

Dean Kenneth Furton College of Arts and Sciences

Dean George Walker University Graduate School

Florida International University, 2009 
(C) Copyright 2009 by Karyna Do Monte

All rights reserved. 


\section{DEDICATION}

I dedicate this thesis to my mother and to Fernanda, Ana Maria, and Ricardo. With their love, support, and patience, the completion of this work was made possible. 


\section{ACKNOWLEDGMENTS}

I wish to thank the members of my committee for their support, encouragement, and patience. Dr. Whitney Bauman was most helpful in guiding my direction in this thesis, and his interest in the subject matter made his guidance inspiring. I am grateful to Dr. Christine E. Gudorf for sharing her deep knowledge of Christian theology with me whenever possible and I thank Dr. Oren B. Stier for taking the time to carefully guide me along the thesis-writing process and for always expecting the best from me. My experience has been immensely rewarding, and it has been an honor to work with such bright scholars. 


\section{ABSTRACT OF THE THESIS}

\section{ENVIRONMENTAL STEWARDSHIP AND THE FATE OF THE BRAZILIAN}

AMAZON: A CASE STUDY OF THE MADEIRA COMPLEX

by

Karyna Do Monte

Florida International University, 2009

Miami, Florida

Professor Whitney Bauman, Major Professor

The present paper analyzes a case study of the Madeira Complex, which plans to build two massive dams on the Amazon River's largest tributary, to identify religious discourse in ecological debates. Three sides of the debate are investigated in order to analyze the various perspectives of proper human relations with the rest of nature that emerge. The Brazilian government and large corporations support the project as a necessary step to meet future national energy needs, the indigenous groups settled in federal territories that are directly affected by the environmental impact of the project and have mixed opinions, and environmentalist organizations starkly opposed to the project because of its impact on the environment. Each perspective reflects a Christian model of stewardship, where humans are responsible for the management of the rest of nature, and even the indigenous worldview adapts this dominant perspective in order to gain visibility in the debate. This debate reveals how the stewardship model can be a subtle form of neocolonization of indigenous people and of ecosystems. 


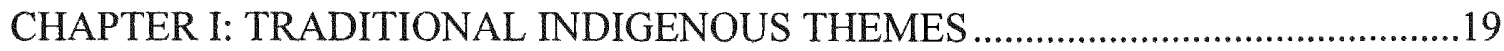

Pre-Contact Indigenous Amazonian Society .............................................................19

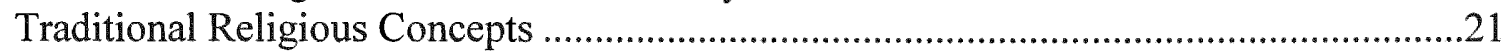

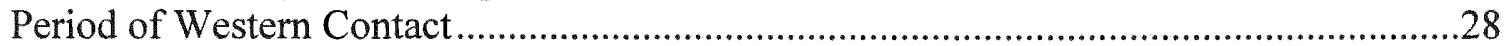

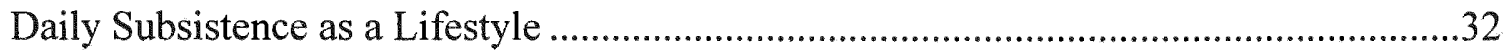

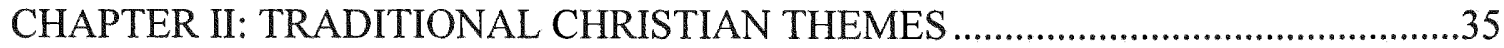

Bestowal of Dominion in the Creation Accounts .........................................................38

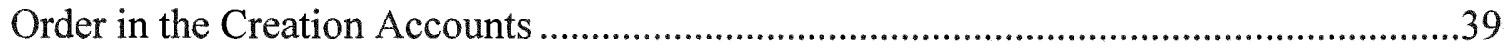

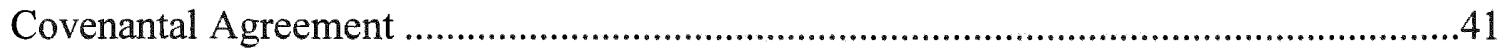

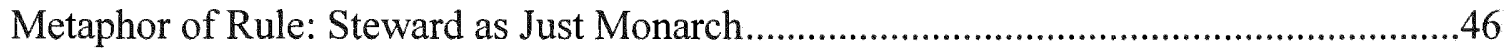

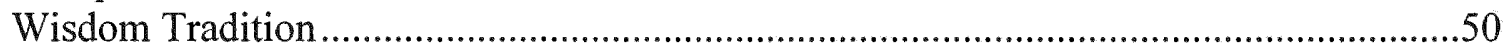

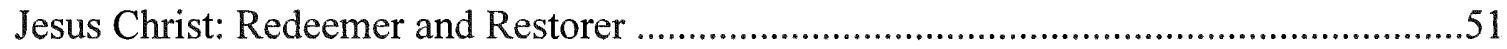

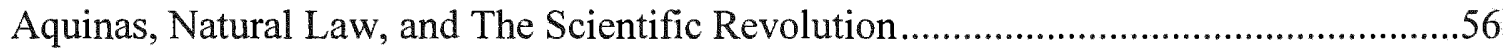

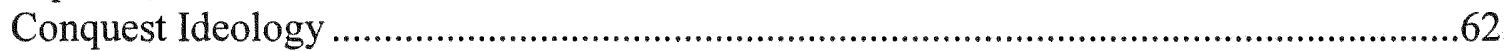

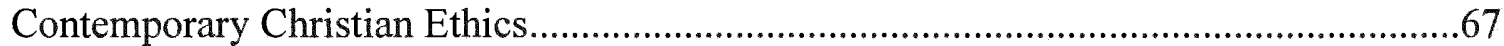

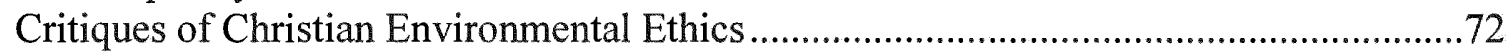

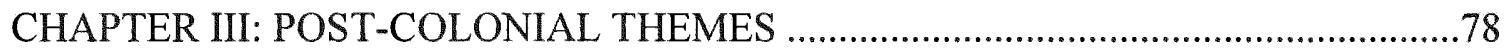

Exchanges: Goods and Ideas and the Occident-Amazon Relationship ............................79

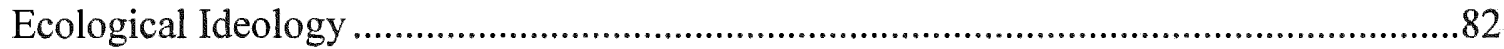

Indigenous Struggle for Rights and the Issue of National Identity ..................................86

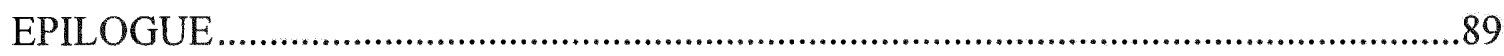

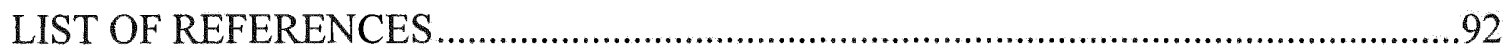




\section{INTRODUCTION}

The landscape of the Brazilian Amazon rainforest is changing rapidly as a debate rages over the proper use or conservation of this vast and unique ecosystem.

Technological advances that allow for large-scale timber extraction, soy cultivation, and the harnessing of hydropower are increasingly changing the physical landscape in the Amazon region. Agricultural and extractive activities in the region are conceived of in terms that include concepts such as national progress, ecological destruction, colonialism and indigenous genocide. Federal demarcation of Indigenous Territories (TIs) in the Amazon rainforest, and especially those in the last twenty years that coincide with the 1988, revised Federal Constitution, ${ }^{1}$ advance at a slow but steady pace and transform the legal landscape. Indigenous territories in the Brazilian Amazon are a coveted location for multinational corporations to expand their production and, thus, a means to attract foreign and domestic capital investment to Brazil that will build the infrastructure needed to put Brazil on the global economic map. The Amazon rainforest is also a cherished ecosystem among environmentalists who agree that the unique blend of high biodiversity, oxygen supply, carbon offset value, and fresh water production, coupled with the plight of endangered indigenous groups who identify themselves as kin to the landscape, make it an important place to conserve. The debate ensues as the landscape changes.

${ }^{1}$ Article 231 of the Federal Constitution, issued on October 5, 1993, recognizes the "cultural and territorial rights of indigenous peoples based on their traditional heritage" including "the exclusive use of the natural resources necessary for securing their cultural integrity and welfare" and "protection against invasion of their territories." Beto Borges and Gilles Combrisson, "Indigenous Rights in Brazil: Stagnation to Political Impasse," SAIIC [Database Online]; available from http://saiic.nativeweb.org/brazil.html; Internet; accessed 3 February 2009. 
One method of exploring the debates over the changing physical, social and ideological treatment of the Amazon rainforest is through a case study that reveals the power dynamics and complicating factors involved. I use as a case study the current plan to build two massive dams on the Madeira River in the state of Rondonia, Brazil, known as the Madeira Complex. In terms of the physical changes to the Amazon rainforest, this project includes three main extractive activities, namely, production of timber, soy, and hydroelectricity. The Madeira Complex is a problematic plan for several reasons. First, the estimated flood area that will result from the dams includes TIs, but indigenous groups have been kept out of the decision to approve the project and are in protest of the ecological cost associated with it. Second, the project is subject to many criticisms, including dodgy dealings between the government and big businesses with regards to licensing and auctioning. For instance, the Brazilian president forced the Brazilian Institute of Renewable Natural Resources (IBAMA) to conditionally approve a license despite discrepancies and inaccuracies in the Environmental Impact Assessment Report (EIA). ${ }^{2}$ Third, the EIA was generated by a consortium comprised of the multi-national, Odebrecht, and the state-owned utility, Furnas, before the project went to auction in order to gain leverage as professed experts regarding the project and also in order to expedite

${ }^{2}$ IBAMA refused to approve licensing for the Madeira Complex without further studies regarding environmental viability in mid-2007. Brazilian president, Luiz Inacio Lula da Silva, ordered a bifurcation of IBAMA into a licensing agency and a separate agency responsible for conservation. He then forced IBAMA to conditionally approve the license so that the project could proceed to the bidding stage. The conditional license was issued with 33 provisions on July 9, 2007. "Empreendimentos do rio Madeia recebem licença prévia do Ibama," in Noticias Ambientais [journal on-line]; available from http://www.ibama.gov.br/novo ibama/paginas/material.php?id arq=5401; Internet; accessed on 10 September 2007. Also, see Glenn Switkes, "Brazilian Government Moves to Dam Principal Amazon Tributary," in Bank Information Center, 12 June 2007 [journal on-line]; available from http://www.bicusa.org/en/Article.10258.aspx; Internet; accessed 12 September 2007. 
the licensing process. Public opinion on the ethics of this project ranges widely. Those in favor of the project argue it is a necessary component in the country's energy strategy while those opposed believe that the social and ecological costs of the project far outweigh the benefits.

The Madeira River is the Amazon River's second largest tributary, "responsible for approximately $15 \%$ of the water volume and $50 \%$ of the sediment ... [that $].$. regulates the biological systems of vast flood plains along the Madeira and Amazon Rivers." ${ }^{3}$ The Madeira River is also home to over seven hundred species of fish, eight hundred species of birds, and hundreds of terrestrial flora and fauna species that live in symbiosis with the river. ${ }^{4}$ The Madeira Basin is home to numerous endangered mammals, including the spotted jaguar, giant anteater, giant armadillo, and giant otter. ${ }^{5}$ The dourada catfish swim upriver each year to reproduce and are a major component of the regional diet; the population in the city of Porto Velho consumes 5 to 6 tons of fish

${ }^{3}$ Lúcia Ortiz, et al., "The Amazon River's Largest Tributary is Under Threat," Friends of the Earth Brazil, et al. trans. Anne Wilson [database on-line]; available from http://www.foei.org/en/get-involved/take-action/RIO MADEIRA.pdf; Internet; accessed 10 September 2007.

4 "Relatorio de analise do conteudo dos estudos de impacto ambiental (EIA) e do Relatorio de Impacto Ambiental (RIMA) dos aproveitamentos hidroelétricos de SantoAntonio e Jirau, no Rio Madeira, Estado de Rondonia," Ministerio Publico do Estado de Rondonia, 61 [database on-line]; available from http://www.mp.ro.gov.br/web/guest/Interesse-Publico/Hidreletrica-Madeira; Internet; accessed 13 September 2007. (Translation of title: "Report on the Analysis of the Content of the Environmental Impact Assessment (EIA) and the Report on Environmental Impact (RIMA) of the Hydroelectric Dams in Santo Antonio and Jirau, on the Madeira River, State of Rondonia," issued by the Public Ministry of the State of Rondonia).

${ }^{5}$ Glenn Switkes, "The Amazon Under Threat: Damming the Madeira," International Rivers Network [database on-line]; available from http://www.irn.org/pubs/factsheets/madeira/MadeiraFact.pdf; accessed 12 September 2007. 
daily. ${ }^{6}$ The Madeira is also home to several thousand settled agrarian and fishing people as well as to over 52 indigenous tribes who depend on the biodiversity for subsistence as well as for preservation of their culture.

The debate regarding the Madeira Complex has several angles. One such angle aligns development with national progress; after all, the Brazilian flag states the national motto of "Order and Progress." The Madeira Complex is the "the cornerstone of the Brazil-Bolivia-Peru hub of the Initiative for the Integration of South American Infrastructure, or IIRSA."7 The Madeira Complex is the first part of a series of plans to construct hydroelectric dams that double as waterways for barges to efficiently transport natural resources and agriculture/animal products out of the Amazon region to global markets. The main ethical argument used to justify this initiative is articulated in the World Bank report entitled "Environmental Licensing for Hydroelectric Projects in Brazil: A Contribution to the Debate," which states:

By 2015 hydropower will provide around 75\% of Brazil's electricity. . . Brazil's economic growth could be compromised if the country is unable to expand capacity in a predictable manner, and within a reasonable time frame. ${ }^{8}$

Official projections for the next decade point to electricity demand increasing annually by $4.4 \%$... Hydropower plants represent $85 \%$ of the installed capacity

${ }^{6}$ Ortiz, Largest Tributary is Under Threat, 7.

${ }^{7}$ Switkes, Amazon Under Threat, 2. IIRSA is a "dialogue forum intended to promote the development of transportation, energy and communications infrastructure from a regional viewpoint, aimed at the physical integration of the twelve South American countries and the achievement of an equitable and sustainable territorial development pattern. "IIRSA Presentation," IIRSA [database on-line]; available from http://www.iirsa.org//CD IIRSA/Index.html; Internet; accessed 3 February 2009.

8 "Environmental Licensing for Hydroelectric Projects in Brazil: A Contribution to the Debate,"Brazil Country Management Unit Economic and Sector Work, Latin America and Caribbean Region, vol. 1, Summary Report, 28 March 2008; available from http://go.worldbank.org/H6SU1Qc800; Internet; accessed 10 February 2009. 10. 
of Brazil's interconnected energy grid. ... It is forecast that hydropower plants will continue to play a predominant, but decreasing, role in the Brazilian energy matrix. ${ }^{9}$

The economic incentive for building the Madeira Complex is that it opens the area to further agricultural development and cattle production. The planning stage of the project alone caused a sharp increase in deforestation, not only of the area surrounding the proposed location of the power plants, but also due to the influx of illegal loggers and cattle and soybean farmers: "In southern Rondonia, portions of the Amazon forest have already lost $80 \%$ of the forest, which has been turned into pasture land." ${ }^{10}$ While the regulatory agencies will crack down on illegal loggers, the national agenda seems to be aligned with accelerated extractive production in the region.

Another angle in the debate comes from the communities directly impacted by the Madeira Complex, who protest being forced to leave their land. These marginalized citizens are overlooked in the bigger picture; they wind up on urban peripheries, destitute and structurally unemployed as their agrarian way of life is shattered. Evidence from previous large-scale big business development projects that displace people indicates that a one-time payment for their fertile lands will be made. While the lump sum is more than many of these people have ever seen, they will find the funds quickly exhausted in an urban environment. Fransico and Teresinha sold their 300 hectare plot of land in the northeastern state Belem for USD $\$ 5,000$ to the agricultural multinational Cargill, which

${ }^{9}$ World Bank, Environmental Licensing, 16.

${ }^{10}$ Charles Nisz, "Madeira's Preliminary License Contributes to Deforestation in Rondonia," Amigos da Terra, Sao Paulo Brasil, 23 October 2007 [journal and database on-line]; available from http://www.amazonia.org.br/English/noticias/print.cfm?id=254888; Internet; accessed 5 January 2008. 
recently moved into the nearby city of Santarem to build a shipping dock and soy manufacturing plant. The couple bought a tiny home in the periphery zone of Santarem and quickly found that their money had been exhausted. ${ }^{11}$ Community members who refuse to give up their lands are often threatened and violently forced to leave their land. Whether the threat comes in the form of burning houses, as it did in Santarem, or by devastating floods resulting from the dam and making the land uninhabitable, the several thousand people who live in the areas impacted by the Madeira Complex must leave.

The indigenous groups actually living on indigenous territories that the Madeira Complex will impact represent yet another perspective. They have had no role in the decision-making process, and are appealing to all levels of the government, asking for their right to preside over matters that affect their territory. On October 31, 2006, CUNPIR (the Federation of Indigenous Organizations of Rondonia, the Northeast Mato Grosso, and Southern Amazon) and the APK (Association of the Indigenous Peoples Karitiana and Kapivari) petitioned the superintendent of IBAMA on behalf of the indigenous groups including the Kaxarari, Katawixi, and Karipuninha (isolated groups in the Indigenous Territory of the Karipuna and Karitiana). The petition states that all of these tribes will be directly and/or indirectly affected by the project, but many of them were not mentioned in the EIA. Indigenous activists working for the rights of the indigenous population of the Amazon are not opposed to development per se, and seek to be a part of deciding which methods and resources should be developed. They also seek governmental promises of healthcare, land rights, education, and that their public voice

${ }^{11}$ Todd Southgate, dir. and ed., "Amazon Deforestation (Soy)," (Greenpeace 2005), on-line film; available from http://vodpod.com/watch/825973-amazondeforestation-soy?pod=jimimiji; Internet; accessed 24 January 2009. 
will be acknowledged. They recognize the need, on the national level, for development of resources for energy sources and economic development, but they demand that the various costs of development projects be accurately assessed.

In the case of the Madeira Complex, they are speaking out and have the support of many environmental groups, NGOs, and public interest groups. ${ }^{12}$ Indigenous groups protested the Madeira Complex on environmental and social grounds. On November 2830, 2007, the Forum of Indigenous Amazonians held a demonstration in Porto Velho, Brazil in response to the Madeira Complex auction. They spoke in opposition to the negative consequences the project will have on socio-cultural diversity, biodiversity in TIs, health and education of indigenous people, global environmental impact, and on behalf of the environmental services provided by indigenous peoples. The strength in their declaration lies in the argument that TIs are "barriers against deforestation, and contribute significantly in offsetting global warming, climatic changes, which currently threaten the lives of humanity and of the planet." 13

It is still to be determined whether indigenous knowledge of native rainforest species will be noted as a necessary "component of any global conservation or sustainable use strategy"14 and will aid them in gaining an invitation to the governmental/big business discussion on development. However, such an invitation comes with the risk of indigenous groups being considered as fully assimilated into the

${ }^{12}$ An extensive list of the movements, networks, organizations, and communities that oppose the Madeira Complex is provided in Ortiz, Largest Tributary Under Threat.

13 "Fórum dos povos indígenas da Amazônia chega ao fim com protesto contra usinas do Rio Madeira," Rio Madeira Vivo, 1 December 2007 [database on-line]; available from http://www.riomadeiravivo.org; Internet; accessed 5 January 2008.

${ }^{14}$ Ibid. 
Western agenda. This is an entrapping situation because federal protection of indigenous people is contingent upon their non-assimilation into Western society, and is planned to phase out as indigenous groups assimilate into the national agenda. The tension of identifying indigenous people as either excluded from or part of the national agenda contributes to the indigenous group's contradictory claims. As indigenous groups see their identity as indigenous being threatened by their identity as Brazilians, they vacillate between different arguments and platforms.

The final perspective in the debate examined here is that of the scientists and environmentalists completely opposed to the Madeira Complex. These groups' major contribution to the debate has been their informed critique of the Environmental Impact Report, which caused IBAMA and the state of Rondonia to look at the report more critically and to note the gross underestimation made in regards to displaced people, estimated flood zones, estimated financial cost of the project, and estimated ecological costs. The EIA states that 3,000 non-indigenous persons will have to be relocated to accommodate the consequent flood zones associated with the project, and repeatedly discusses the issues that increased labor migration to the region will have on TIs:

Due to the increased migratory flux to the region, there will be pressure on reservation areas and the opening of new occupied fronts on lands that remain preserved, favoring the environmental degradation of areas surrounding TIs, such as the practice of illegal activities such as hunting, fishing, and wood and mineral extraction therein. ${ }^{15}$

According to scientists, the dams may not function properly for long because the amount of sediment that travels along the Madeira will clog the turbines and there is a high risk that the river and surrounding areas will have increased mercury levels. Furthermore,

${ }^{15}$ Report on the Analysis of the Content of the Environmental Impact Assessment (EIA,) Public Ministry of the State of Rondonia, 131. 
scientists state that the EIA underestimates the damage that the Complex will cause to the migratory fish that travel up the Madeira annually. They also note that flooding, logging, and farming/ranching will destroy the region's rich and unexplored biodiversity before it is ever recognized or properly studied. Conservationist organizations are opposed not only to hydroelectricity as an energy source, citing its inefficiency and ecological and social costs, but they are incensed at the proposal to destroy the various rare and, in some cases, endangered, species native to the Madeira River and surrounding lands.

The rhetoric in the debate regarding the Madeira Complex features two commonly used terms to express the appropriate relationship between humans and the rest of nature, "stewardship" and "sustainability." A stewardship model assumes that humans, as uniquely self-aware beings, must care for the rest of nature and are accountable for their treatment of the rest of nature. However, issues such as human overpopulation, over-consumption, and ecological pollution complicate our responsibility over the rest of nature by applying untenable amount of pressure on ecosystems such as the Madeira. In order to be cogent, a stewardship model needs to be articulated in terms of how the role of caregiver relates to human needs and ecological costs. Clarification is required regarding whether stewardship is a form of resource use and management that includes leaving some of nature unused. The stewardship model is useful because it implies responsibility and accountability in human-earth relations, but problematic because it tends to refer to management of nature, which implies humanity is separate from the rest of nature. The native inhabitants of this region do not agree with such a perspective because their identification with the rest of nature is based on kinship, as we will see below. 
A central problem with a model of human-earth relations that is based on management is seen in the term "sustainability," which often refers to the appropriate form of human stewardship of nature. Sustainability refers to a practice that has the "capacity to be practiced or maintained indefinitely ... as well as not undermining ... other practices or systems that would otherwise be sustainable ..." ${ }^{16}$ The 1987 United Nation's Brundtland Report uses the term "sustainable development" to refer to development that "meets the needs of the present without compromising the ability of future generations to meet their own needs." ${ }^{17}$ Sustainable development requires concern for future generations, but it is a term that fails to clarify what constitutes acceptable human needs or ecological costs. The United Nations redefinition of the term in the 1991 report entitled Caring for the Earth addressed these ambiguities by stating that sustainable development should improve the "quality of life while living within the carrying capacity of supporting ecosystems." ${ }^{18}$ This standard is not met by the Madeira project because of the native people who will be displaced and lose their quality of life. It is also a definition that presents the issue of ecological cost in terms of Western notions of quality of life, thus perceiving non-human nature instrumentally. The concept of sustainable development underscores the social dimension of development but fails to acknowledge that the rest of nature has intrinsic value.

Thus stewardship and sustainable development are highly problematic terms

${ }^{16}$ Robin Attfield, Environmental Ethics: An Overview for the Twenty-First Century (Malden: Blackwell, 2003), 127.

${ }^{17}$ Report of the World Commission on Environment and Development. United Nations. 42/187. 11 Dec. 1987. http://www.un.org/documents/ga/res/42/ares42-187.htm; Internet; accessed on 11 March 2008.

${ }^{18}$ Attfield, Environmental Ethics, 128. 
because they can and often do buttress economic progress at the expense of minority interests, marginalized peoples, and conservation of specific biomes. Scientists, environmentalists, and indigenous groups insist that the Madeira Complex is not sustainable or representative of good human stewardship, while the EIA, government officials, and the mainstream media defend it as a sustainable and necessary project. These definitions of stewardship and sustainability used to defend the Madeira Complex as a viable project reproduce a hierarchical model of relations that place (some) humans over and above the rest of nature, instead of attaining just and ecologically sound relationships among humans and between humans and the rest of the natural world. Furthermore, these terms are used despite their ambiguity regarding ecological costs and displaced minority groups to refer to projects such as the Madeira Complex. The physically distanced Western environmentalist is starkly opposed to the Madeira project and sees proper stewardship, that is, human management over natural resources, in terms of inactivity and total conservation and calls for alternative and less ecologically costly forms of energy production such as solar energy.

The perspective in favor of the Madeira Complex, that of the Brazilian government and financially interested companies, presents stewardship in terms that refer to the rest of nature as resources while it assures us that development needs need to be weighed against environmental impact. They present sustainability as compatible with increasing levels of consumption and turn a blind eye to the fact that the Madeira Complex will result in an irreversible transformation of the region and its ecosystems. The perspective that nature must be looked after is a necessary part of a stewardship model, as is the call to use natural resources efficiently and with minimal ecological 
damage. Given this misuse of the terms "stewardship" and "sustainability," why do contemporary environmental voices critical of development of the Madeira Complex, including indigenous voices and NGOs, rally around the stewardship model and notions of sustainable development? How important is the preservation of the Amazon and other unique and vital biomes to these understandings of proper stewardship? Who should oversee and benefit from sustainable development, and who actually benefits? Who determines the viability of a project such as the Madeira Complex? By definition, sustainability implies the longevity of a development project, yet the scientific community warns us that the Madeira is not a viable solution for the long-term. ${ }^{19}$ The successful misuse of terms such as sustainability indicates that these concepts are vulnerable to distortion.

This thesis analyzes religious foundations in human-nature relationships to identify religious rhetoric in the Madeira debate that buttresses models based on stewardship and sustainability. Chapter one is a brief survey of traditional indigenous worldviews in the Brazilian Amazon region. By looking at the social structure and religious concepts of a variety of tribes, I argue that an indigenous Amazonian worldview revolves around the concept of kinship with nature. Landscape is formative in traditional indigenous identity and subsistence living is perceived as a form of negotiation with,

19 "Studies That Don't Hold Water: 30 Errors in the Environmental Impact Assessment for the Madeira River Hydroelectric Complex," International Rivers Network, 1 January 2007 [database on-line]; available from http://www.internationalrivers.org/en/latin-america/amazon-basin/madeira-river/studiesdon $\%$ C2\%B4t-hold-water; Internet; accessed 10 January 2009. Also, see State of Rondonia Report and "Brazil's Sustainable Power Sector Vision 2020- English Summary," World Wildlife Fund (International Rivers Network, 2008) [database online]; available from http://www.internationalrivers.org/en/latin-america/amazonbasin/madeira-river/studies-don $\% \mathrm{C} 2 \% \mathrm{~B} 4 \mathrm{t}$-hold-water; Internet; accessed 11 January 2009. 
rather than stewardship over, non-human nature. Next, the changes that colonial contact had on the traditional indigenous worldview are discussed, and especially those that deal with indigenous identity vis-à-vis non-indigenous groups. Indigenous myths after the contact period reveal a process of syncretism of Christian religious themes that deal with the relationship between humans and nature and explain, at least in part, why indigenous groups speak in terms of Western concepts such as stewardship and sustainability in the Madeira debate. The transformation of indigenous identity due to contact results in a worldview that is self-contradictory because it combines incompatible concepts of traditional kinship with Christian anthropocentrism. This is precisely the point where the indigenous model of kinship is colonized: when indigenous language that represents their cultural identity as integrally bound to a specific place is forsaken in favor of Western stewardship language.

The second chapter explains the religious foundations for the stewardship model based in the Hebrew Bible and Christian Testament. The Christian worldview presents humans as superior to the rest of nature, and interpretations of the quality of this relationship inform the stewardship model. In the example of the life and ministry of Jesus in the Gospels, a renewal movement in the Jewish tradition is presented which overturns the status quo of hierarchy and social stratification in favor of a model of equality and inclusion. Traditional Christian theology on the role of humans vis-à-vis the environment was originally based in the Hebrew tradition and later combined with Greek classical concepts of ordered nature. St. Thomas Aquinas' synthesis of these two schools of thought is summarized to highlight the presence of hierarchy in the Christian concept of stewardship. This theological basis for stewardship remained through the advent of 
modern science beginning in the 15th century, which drew from Aquinas' concept of a Great Chain of Being and the idea of a rational order in nature.

The stewardship model, bolstered by both classical Christian theology and the rise of Western science, is at play in the conquests of the Neo-Americas. The stewardship model is also informed by conquest ideologies based on concepts such as "discovery," "wilderness," and "savage" peoples that need to be "cultivated" or "civilized." In other words, the concept of "stewardship" enters the scientific perspective by way of the union of Christian thought and Greek natural philosophy. It is then reinforced and distorted during Christian European conquest of the "new" world. I conclude the second chapter with a brief survey of contemporary Christian ethics based on stewardship, specifically the work of Michael S. Northcott, Carolyn Merchant, Latin American liberation theologians, and Regina Schwartz to illustrate the critiques of Western colonization as a form of bad stewardship used as a tool of hegemony.

The third chapter of this thesis discusses the Madeira Complex and related socioecological issues and explores alternate models from a post-colonial perspective that identifies Western concepts of human-nature relations as a hegemonic form of colonization. Val Plumwood refers to this ecological hegemony as "a system of power relations in which the interests of the dominant party were disguised as universal and mutual, but in which the colonizer actually prospered at the expense of the colonized." 20 Post-colonial scholars such as Val Plumwood, Anne McClintock, Frantz Fanon, and Carolyn Merchant identify nature and indigenous groups as colonized by the powerful

${ }^{20}$ Val Plumwood, "Decolonizing Relationships with Nature," in Decolonizing Nature: Strategies for Conservation in a Post-Colonial Era. eds. William M. Adams and Martin Mulligan (Sterling,VA: Earthscan, 2003), 51. 
national and international capitalist enterprise that seeks development and quick profit at the cost of the identity of the colonized. Carolyn Merchant offers a salient alternative model of partnership and negotiation as the correct means of dialogical relations between humans and nature.

My analysis draws upon environmental historian Alfred Crosby's exchange theory, which suggests that the competitive strength of Western ideas works in tandem with the competitive advantage of Western flora and fauna in the process of colonization. I argue that the Madeira Complex presents a situation of both internal (national) and imperial (Western) colonization, to use Anne McClintock's nuance as well as her warning that "premature celebration of the pastness of colonialism runs the risk of obscuring the continuities ... of colonial and imperial power. ${ }^{21}$ Post-colonial critiques identify problems regarding the treatment of the Other, in this case, nature or indigenous people, in need of further consideration and visibility. Development projects designed to meet modern economic needs create ecological and social exchanges that are often ignored or minimized until the projects are completed. But Murray Bookchin, the founder of the social ecology movement, warns that,

To separate human beings and society from nature is to dualize and truncate nature itself, to diminish the meaning and thrust of natural evolution in the name of a "biocentricity" that spends more time disporting itself . . than with the realities of the biosphere and the role of society in ecological problems. ${ }^{22}$

${ }^{21}$ Anne McClintock, "The Angel of Progress," in Colonial Discourse and Post Colonial Theory: A Reader, ed. Patrick Williams and Laura Chrisman (New York: Columbia, 1994), 294.

${ }^{22}$ Murray Bookchin, "Social Versus Deep Ecology," in Environmental Ethics: Readings in Theory and Application, $2^{\text {nd }}$ edition. ed. Louis P. Pojman (Boston: Wadsworth, 1998), 162. 
Indigenous protests regarding the Madeira Complex present an emerging indigenous identification with Western concepts of territorial rights as well as increasing economic interests which do not reflect their traditional worldview of kinship with nature. The appropriation of Western values among indigenous Amazonians evidences that exchange is necessary for survival because colonial systems discredit or minimize minority viewpoints. Also, indigenous needs for social aid that will assist them with contact with the West may be seen to correspond with the national agenda of economic progress that involves development of energy and other resources in the Amazon region. Indigenous groups cannot participate in a profit-driven discussion unless they modify their traditions of conserving and living within the forest, which they have done for over five millennia, to better suit the dominant rhetoric. ${ }^{23}$ However, the indigenous protest of the Madeira project makes it clear that, while development may be necessary for human well being, it need not be had at any ecological cost. This is the point where indigenous identification through and in landscape remains part of their worldview. Also, they highlight the fact that most of the acceleration to license the Madeira project had more to do with quick profits than with thoughtful and efficient management of resources.

In Brazil, the political agenda for the indigenous population is commonly referred to as the "Indian Issue," and involves land rights, social welfare and the issue of a separate, indigenous identity versus indigenous assimilation and participation in the larger economic and national system. ${ }^{24}$ The cultural individuality that indigenous groups

${ }^{23}$ Gustavo Politis, "Foragers of the Amazon: The Last Survivors or the First to Succeed?", in Unknown Amazon: Culture in Nature in Ancient Brazil, eds. Colin McEwan, Critiana Barreto, and Eduardo Nieves (London: British Museum, 2001), 48. 
want to maintain conflicts with their acceptance of national goals, which is perceived in terms of the national goal to culturally assimilate indigenous people into Brazilian culture. The indigenous population asks for social welfare from the government on the basis of its difference, thus assimilating runs the risk of becoming less "Indian" and more "Brazilian;" this transition of identity compromises indigenous rights to separate federal protection and indigenous territory. To complicate this issue of identity, there is concern among indigenous groups that the protection they receive will be forfeited if they are perceived as "white." 25

The quest for new energy sources and fresh supplies of natural resources and food-surplus in Brazil presents a conundrum for everyone involved. Energy solutions such as solar generation and refurbishing existing energy sources are not as profitable as the construction of large-scale dams. The indigenous model of daily subsistence consumption is not possible for the largely urbanized communities nor does it lead to participation in the global economy. The idea that human use of nature is benign and thoughtful management is often exaggerated, and terms such as stewardship and sustainability may be used as rhetorical cloaks to disguise the placement of humanity and quick profits over and against the rest of nature. The stewardship model represented by the proponents of the Madeira Complex reproduce hierarchical relationships that remove humans from the rest of nature, and thereby silence voices that might argue in favor of kinship relations with nature. In other words, stewardship may be used to forward yet

24 "Indios: direitos históricos," Caderno de Comissão Pro-Índio, 3 (Sao Paulo: Comissão Pro-Índio, 1982). (Translation of title: "Indians: Historical Rights," Notebook on the Pro-Indian Commission, no. 3).

${ }^{25}$ Ibid. 
another form of colonization, namely, ecological colonization of the Amazon.

Post-colonial discourse offers insight into identity formation and especially the difficulty that lies in trying to maintain a marginalized worldview in the presence of a Western worldview that seeks to assimilate or obscure the Other. Indigenous protest must use concepts that threaten the vitality of their own worldview, including ownership of land and resource development, in order to gain foothold in the debate and find agency in the decision-making process that directly impacts their society. The Madeira debate evidences that terms such as stewardship and sustainability may be distorted so that they no longer refer to the true viability of a development project and overlook negative ecological and social consequences. 


\section{CHAPTER I: TRADITIONAL INDIGENOUS THEMES}

It is difficult to reconstruct a genuine traditional indigenous worldview because any ethnographic record to date involves Western documentation of indigenous testimony. Some ethnographic records include testimony of indigenous beliefs that seem too alien for Western notions to be appropriated, and these are referred to as "traditional." A survey of different tribes in the Brazilian Amazon region reveals the traditional indigenous worldview as one that fosters an intimate regard towards nonhuman nature. Pre-Contact Indigenous Amazonian Society

As far as can be discerned today, traditional Amazonian indigenous villages were semi-temporary structures configured either in a linear or circular shape and both configurations delineated "internal" tribal space protected from the "external" environment. The central house in the village was the communal hut exclusive to the village men and surrounded by women's huts. The division between the village and the forest was constructed more mentally than physically, and a physical barrier did not demarcate it. Among the Kayapo, the circular configuration of the women's huts around the central men's hut created a spatial demarcation between human society and the outer forest, "the land immediately surrounding the circle of houses was called the 'black' or 'dead' ground and was conceived of as a transitional zone between the social space of the village and the natural domain of the savannah or forest." ${ }^{26}$ The village literally existed in nature and lacked dividers used in Western society such as windows, doors, and gates to conceptualize the division between "private/home" and "public" spaces. Nilo dos

${ }^{26}$ Terence Turner, "The Sacred as Alienated Consciousness: Ritual and Cosmology Among the Kayapo," in Native Religions and Cultures of Central and South America (New York: Continuum, 2002), 282. 
Santos Conclaves, a Bear tribe indigenous elementary school teacher in the Sao Francisco village, confirms that an indigenous home is within nature, "Here, the houses have no walls, and we live in communal harmony." 27

The Kayapo people of the Xingu (riverine) region had a basic rule of matriuxorilocal ${ }^{28}$ marriage but most of their ceremonies and rituals were mainly rites of passage that "emphasize the importance of extra nuclear family relations. ${ }^{29}$ Bestowal of seniority (Turner calls this "dominance" or "preeminence") and of metch, or beauty, through the exchange of gifts of names and of symbolic material objects characterized Kayapo ritual ceremony. The Kayapo showed their stage in the linear human life cycle through ornamentation of their bodies using natural dyes and pieces of wood and bone. For the Kayapo, bestowal of names and physical ornamentation were a conscious construction of social identities distinct from all the groups they came into contact with: "the autonomous village community remained for practical social purposes the highest level of integration of Kayapo society ..." ${ }^{30}$ Denise Gomez explains that body painting among the Tapajo is also used to construct and transform identity, "the body can be seen

27 "Amazonia Lives," The Visual Conscience: Dedicated to Finding Images From Around the World That Speak to Our Conscience, 22 August 2007 [journal on-line]; available on http://thevisualconscience.blogspot.com/2007/08/amazonia-lives.html; Internet; accessed 30 November 2008.

${ }^{28}$ This anthropological term is used to refer to marriages where a husband lives with his wife's kin. "Uxorilocal Residence," in Encyclopedia Britannica (2009) [encyclopedic database on-line]; available from http://www.britannica.com/Ebchecked/topic/620995/uxorilocal-residence; Internet; accessed 20 February 2009.

${ }^{29}$ Turner, Sacred as Alienated Consciousness, 279.

${ }^{30}$ Ibid., 282. 
as a 'canvas' upon which an individual's social identity can be transformed and constructed." ${ }^{31}$

While humans act in these social contexts, they also have kin animal spirits and spiritually adept humans such as shamans can experience their animal being by entering into a trance state. Indigenous traditions teach that there is more than one type of spirit in the world, and that each spirit is a form of person-hood. What is interesting about indigenous Amazonian understandings regarding person-hood is that non-human beings are also persons. The most prevalent example of this is seen in the jaguar and the tapir, which are considered sacred ancestral human spirits among various tribes. ${ }^{32}$ Gustavo Politis explains that, among the Nukak Maku of the northwest Amazon, "every person has three spirits" that dwell in different realms such as the "house of the tapir."133 This is a great example of the understanding among many Amazonian indigenous groups that animals and humans are kin.

Traditional Religious Concepts

Indigenous Amazonian myths evidence that when there is belief in a hierarchy of being, it does not place humans on the top rung. These stories do not indicate that humans

${ }^{31}$ Denise Gomes, "Santarem: Symbolism and Power in the Tropical Forest," in Unknown Amazon eds. Colin McEwan, Cristiana Barreto and Eduardo Neves. trans. Benjamin Alberti (London: British Museum Press, 2001), 142.

${ }^{32}$ See Carlos Fausto, "If God Were a Jaguar: Cannibalism and Christianity Among the Guarani (16th-20th Centuries)," in Time and Memory in Indigenous Amazonia: Anthropological Perspectives. eds. Carlos Fausto and Michael Heckenberger (Tallahassee: University Press of Florida, 2007); Gustavo Politis, "Foragers in the Amazon: The Last Survivors or the First to Succeed?", in Unknown Amazon: Culture in Nature in Ancient Brazil. eds. Colin McEwan, Cristiana Barreto and Eduardo Neves. trans. Benjamin Alberti (London: British Museum, 2001); and John Bierhorst, The Mythology of South America (Oxford: Oxford, 2002).

${ }^{33}$ Politis, Foragers in the Amazon, 46. 
are superior to animals and the larger environment, but they evidence that indigenous people derive spiritual as well as material well being from these other life forms. Tales about the beginning of time depict humanity arising from the activity of animals, and the first humans often rely on their relationship with animals in order to survive. This motif sheds light on the traditional indigenous view that human life and nonhuman life are continuous, and that the bridge between these different embodiments is one that can be crossed easily. The indigenous worldview in the Amazon region is based on the belief that the present world is one of many cosmological epochs and that humans' ritual activities maintain harmony with ancestor spirits who have taken animal and plant forms. Non-animal life forms such as planets, stars, trees and rivers are also central in the indigenous model of the cosmos. For example, the Kayapo design of the cosmos replicates the linear process of the growth of a plant or tree; the East is the "root" of the sky and the West is the "tip" of the sky. ${ }^{34}$

John Bierhorst's compilation of indigenous South American mythology identifies basic themes such as origin stories, "of food, fire, sex, work, and death." ${ }^{35}$ I overlook his reduction of myths into two main types of myths, the "Twin Myth" and the "Tree and the Flood" myth, because it seeks only to compartmentalize them into a larger system. While over-simplification of indigenous mythology into larger categories makes them manageable to a foreign audience, it bears the risk of the generalization of highly diverse localized traditions. However, the broad strokes Bierhorst draws, such as his systematized summary of Stith Thompson's list of 150 South American motifs into less than thirty

\footnotetext{
${ }^{34}$ Turner, Sacred as Alienated Consciousness, 282.

${ }^{35}$ Bierhorst, Mythology of South America, 11.
} 
main traits, is useful in painting an image of how indigenous groups conceptualize human-nature relationships. Also, Bierhorst rightly notes that, while some Amazonian groups have been classified in the Smithsonian Institution's Handbook of South American Indians $^{36}$ as "marginal" cultures because of their size in comparison to the larger tribes in the "Tropical Forest" category, their common geography merits that their myths be classified according to that criteria rather than by population. ${ }^{37}$

Bierhorst's work on Amazonian indigenous groups, which he classifies as "Greater Brazil," identifies the jaguar as a common mythological hero/trickster, who "is seldom able to act on his own. ${ }^{138}$ In some creation myths, the jaguar works with a human to create the world, such as in the (extinct) Tupinamba tribe's sacred twin myth, which tells of an old jaguar lady who protected the impregnated ancestor mother from being eaten by her jaguar son. ${ }^{39}$ In this tale the mother transforms into a doe and is killed by the son jaguar. The jaguar lady takes the woman's children and raises them. The story tells us that every day, the sons "changed themselves into different animals." ${ }^{40}$ Common themes in this myth are the facts that jaguars are the highest beings on the food chain and the continuity shown by humans shape-shifting into animals and by the jaguar lady raising human children. The creation account characterized by human "dominion" or

${ }^{36}$ Alfred Metraux, "Tribes of the Middle and Upper Amazon River," in Handbook of South American Indians. ed. Julian H. Steward, vol 3 (New York: Cooper Square Press, 1963).

${ }^{37}$ Bierhorst, Mythology of South America, 18.

${ }^{38}$ Ibid., 26.

${ }^{39}$ Ibid., 30.

${ }^{40} \mathrm{Ibid} ., 30$. 
"stewardship" over the rest of the natural world is not something derived from these myths.

Cosmological myths illustrate that the generative qualities of species are in fluid exchange during the dawn of human creation. Interspecies sexuality becomes taboo in tribal society, but continues to be a motif in their mythology that reflects inter-species kinship. $^{41}$ The Amazonian Yagua tribe recounts the creation of fish from wood chips cut from the large lupuna tree. ${ }^{42}$ Among the Apinaye tribe, humanity is created when the sun god throws gourds into the Tocantins River. ${ }^{43}$ The Suruí of Rondonia's tales include men who "were once people and are now plants" and trees. ${ }^{44}$ These examples illustrate how an indigenous group sees creation of one species as originating from another species. The lupuna tree in the Yagua tale is also the source of drinking water. ${ }^{45}$ Clearly the relationship between the resources that sustain humans and their creation are structured in such a way that animals, plants, and rivers precede and create humans.

A deep animistic understanding of all forms of life pervades indigenous discourse about the environment so that the animals, plants, rivers, etc are each imbued with a spirit that participates in tribal life. The concept of the spiritual double, whether in a cosmological myth of the first humans as twins or of the dual spirit nature of the shaman,

${ }^{41}$ See John Bierhorst, The Mythology of South America (Oxford: Oxford, 2002) and Betty Mindlin and Surui Indians, Unwritten Stories of the Surui Indians of Rondonia (Cincinnati: Sibylline, 1995).

${ }^{42}$ Bierhorst, Mythology of South America, 31.

${ }^{43}$ Johannes Wilbert. ed. Folk Literature of the Ge Indians (Los Angeles: University of California, 1978), 74.

${ }^{44}$ Mindlin, Unwritten Stories of the Surui, 10.

${ }^{45} \mathrm{Ibid} ., 28$. 
reflects the belief that humans have more than one embodiment. Ethnographer Robert Murphy's detailed study of the Mundurucu tribe of Para, Brazil explains that "spirits and supernatural powers are active agents ... and the constant manipulation and propitiation of them are essential to the life and the well being of the tribe." ${ }^{46}$ The worship of sacred beings represents the belief in multiple spirits and multiple realms of existence inhabited by human and non-human spirits. The Ge explain the origin of propitiary acts as repaying favors done on behalf of humans by other species. For example the Ramkokamekra Ge tribe repay the fish who saved their mythic hero, Poretey's life with a festival in their honor. ${ }^{47}$

Another aspect of traditional indigenous Amazonian life is the worship of sacred objects. Myths regarding sacred objects illustrate how the sacred story can establish cultural functions and act as a social charter. The Mundurucu story of their sacred flutes, karöko, tells that they are taboo to the sight of women, though it was women who discovered them. This myth validates the ascendancy of males in Mundurucu society. ${ }^{48}$ Because the men had to rebel against women in primal times, women do not consider themselves the inferior sex. ${ }^{49}$ The same ritual that the women performed when originally bringing the karökö into the village is performed each time the society moves to a new location; during this ceremony, the other sex must stay inside of the surrounding dwelling houses while the trumpets are installed in a walled room inside of the central eksa. The

\footnotetext{
${ }^{46}$ Murphy, Mundurucu Religion, 12.

${ }^{47}$ Wilbert, Ge Folklore, 236-237.

${ }^{48}$ Murphy, Mundurucu Religion, 89.

${ }^{49}$ Murphy, Women of the Forest, 117.
} 
$e k s a$ is now the men's house because, as the hunters, they are considered the rightful guardians of the karökö. The myth is seen functioning where a differentiation is made with regards to rank, power and subordination. ${ }^{50}$ In a traditional society, it marks the solidarity of men in hunting practices as well as the complementary division of labor among women as horticulturalists and men as hunters.

The karökö myth also deals with economic concerns, acting as the backdrop for the interactions made between Mundurucu men and women in their daily lives. Even when men and women work together establishing gardens, they perform separate tasks. The men clear the land, and the women plant the seeds. The division of labor is not attributed to physical strength, but to men's unique hunting skills and women's unique role as mothers. The Araiarai and Dajearuparip ceremonies held in honor of the mother game spirits gave the Mundurucu a way to commune with the spirit world, and reinforce their belief that their lives were fully dependent on nature. This time of celebration brought villages together to feast and express their religious beliefs; song and dance were used to preserve the oral tradition. Ceremonies were held during the lull of the rainy season and livened the days when this society usually rested. The connection between subsistence living and sacred flutes gives example of how the physical world is imbued with spirit and acts with or against humans. The sacred flutes are not, as anthropologist Jean-Pierre Chaumeil argues in his essay entitled "Bones, Flutes, and the Dead: Memory

${ }^{50}$ Bronislaw Malinowski, Magic, Science and Religion and Other Essays (Garden City, NY: Doubleday Anchor, 1954), 126. 
and Funerary Treatments in Amazonia," ${ }^{51}$ a symbol of bones, but actually the sanctification of hollow tubes used for poison fishing.

Indigenous myths clearly live "in the cultural context of tribal life and not merely in narrative." 52 Bronislaw Malinowski's critique of the recorded myth as the dead myth has a deeper meaning, for "in all this it is once more clear that we can neither fully grasp the meaning of the text, nor the sociological nature of the story, nor the natives' attitude towards it and interest in it, if we study it on paper." ${ }^{, 53}$ But indigenous identity does not simply die, it transforms and through myth the past is recorded and transmitted in the society. The decline in traditional beliefs dealing with the harmony between humans and nature is a function of their new economically based relationship with natural resources. As for the relationship between religion and social structure degenerates "as the society has become progressively divested of those mechanisms that integrated tribe and village, so also have group religious activities fallen into abeyance." 54 This demonstrates that the human-nature reality among Amazon's indigenous people is dependent on physical place and unable to be transported. It also demonstrates that the linear concept of development, which allows for relocating humans out of their original eco-context and putting them in a physical location where they are dominated by economic dealings where they are overpowered by their colonizers is a form of cultural genocide.

${ }^{51}$ Jean-Pierre Chaumeil, "Bones, Flutes, and the Dead: Memory and Funerary Treatment in Amazonia," in Time and Memory in Indigenous Amazonia: Anthropological Perspectives, eds. Carlos Fausto and Michael Heckenberger (Tallahassee: University Press of Florida, 2007).

$$
\begin{aligned}
& { }^{52} \text { Ibid., } 145 . \\
& { }^{53} \text { Malinowski, Magic and Religion, } 106 . \\
& { }^{54} \text { Murphy, Mundurucu Religion, } 139 .
\end{aligned}
$$


The transformation of indigenous worldviews in the Brazilian Amazon began with European contact in the 16th century and went through a series of subsequent stages of contact and non-contact associated with either the presence or lack of missionary settlements combined with the presence of extractive activity of Western settlers and traders in the region. Ethnographic records indicate that contact with Christian ideas of brotherly love and of asceticism, especially associated with vegetarianism, changed the religious landscape for some tribal groups such as the Guarani tribes of Brazil and Paraguay. ${ }^{55}$ Robert Murphy's study of the Mundurucu of the Para region in northern Brazil concludes that the religious worship of human heads associated with inter-tribal warfare began after contact and operates as a release-valve for aggression as well as a unifying force in the group.

The degree of proselytization and/or economic contact with Western society results in a variety of transformations in the indigenous religious worldview. The initial contact and threat of whites in Mundurucu society was successfully challenged by a century of warfare. In this period, the Mundurucu used their aggression to protect tribal bonds in their societies. By enlisting young men into the war parties, using trophy heads ceremonially and directing their aggressions outside of the society, they retained a cohesive structure. Their reliance on Western goods was minimal, and their relationship with nature was intimate. Living in a cooperative setting ensured that all members of society had support in their daily lives that extended beyond the nuclear family.

${ }^{55}$ Carlos Fausto, "If God Were a Jaguar: Cannibalism and Christianity among the Guarani (16th-20th Centuries)," in Time and Memory in Indigenous Amazonia: Anthropological Perspectives, eds. Carlos Fausto and Michael Heckenberger (Tallahassee: University Press of Florida, 2007). 
Mundurucu myths recount contact with the non-indigenous pariwat in terms of the material exchanges that occurred during the 19 th century rubber boom. In this myth, we see a note of the enchantment indigenous people may experience when they are introduced to Western technologies:

The three chiefs fought the whites at first, but then the white men captured two Mundurucu boys and raised them. These boys were sent back to tame the Mundurucu and with them they brought baskets full of steel axes, hoes, machetes, and other articles. . . and explained to the warriors that the whites merely wanted to tame them and not to harm them... The old men were impressed and accepted the white men. ${ }^{56}$

This initial fascination with Western commodities may have worn off by the time of Robert and Yolanda Murphy's studies of the Mundurucu in the 1950s. The rubber boom consumed the lives of the tribe, who now extracted valuable latex from trees and conducted business with the tradesmen. This economic relationship marked the end of traditional savannah villages, replaced by scattered dwellings consisting of nuclear families. Residence shifted closer to the principal trade route, the Cururú River, and fish became the main protein source. The shift in diet alone broke the social ties between the men, who once shared in warfare and hunting and bonded in the men's hut. The rigidity of complementary sexual division of labor broke down as well. Modern Mundurucu society lacks the cooperative elements that produced a cohesive social structure. In the case of the Mundurucu, proselytization gained way only after these economic ties were established. ${ }^{57}$ Mundurucu myths and customs clearly would not

\footnotetext{
${ }^{56}$ Murphy, Mundurucu Religion, 132.

${ }^{57}$ Ibid., 133.
} 
survive the contact with the pariwat because their social function disintegrated with the change in their geographic, social and economic structures.

Indigenous religiosity depends on the relationship that a tribe has to the nonhuman world. The practice of cannibalism among the Guarani is deeply connected to game hunting as well as to their belief in the supernatural power of jaguars. Jaguars embody a "double" identity of human and nonhuman existence. Traditional shamans are kin with jaguars and are also believed to inhabit the human world and have access to embodied experience in the nonhuman jaguar world. Carlos Fausto explains the replacement of cannibal religious rites with a concept of afterlife in the supernal realm, "Land-Without-Evil" and a migration based on eschatological hope, where the tribe is:

led by shamans who announced the imminent end of the world and called on people to follow them, amid chanting and dancing, to a land of plenty with no disease or death, which was often believed to lie overseas. ${ }^{58}$

Jesuit missionary efforts also resulted in shamans appropriating Catholic rituals and objects, so that "what was at stake was not a conflict between 'two' religions" but an acquisition of Catholic rituals and objects as part of their autonomous religiosity. ${ }^{59}$ Aparecida Vilaça explains that self-identification through the use of Western aesthetics among the Wari' tribe of the southern Amazon is based on their traditional worldview. The decision to don Western garb, to wear any clothing, or to increase or decrease use of bodily ornamentation reflects the indigenous belief that identity is partially constructed by these embodiments. The "choice of body" is usually constructed

\footnotetext{
${ }^{58}$ Fausto, If God Were a Jaguar, 79.

${ }^{59}$ Ibid., 82-83.
} 
in pairs, and this reflects the traditional belief that humans and ancestral beings often have more than one embodiment:

the process of contact with whites is conceived through the prism of shamanism. Just as shamans are simultaneously human and animal, the Wari' today possess a double identity: they are both Wari' and white. ${ }^{60}$

There is a similar continuity in the belief in double-identity among the Guarani that allows them to consider themselves both white and indigenous that disrupts "the traditional networks of cultural transmission while simultaneously expanding the possibility of cultural reinventions." ${ }^{61}$ Indigenous images still act as an important symbol in political discourse, one that is used in order to impress the importance of cultural identity in light of the difference it illustrates to Western audiences. ${ }^{62}$

With the decline of communal ceremonial gatherings, individual practice of sorcery increased among the Mundurucu. Belief in malevolent magic and the power of illness is a function of feeling vulnerable to the reality of external threats to their society. The myth is still at work here because all disease is believed to be caused by witchcraft, but now the natural state of "strength, vigor, and bodily perfection" is enshrined in their religious stories about the past. ${ }^{63}$ Sorcery in Mundurucu society functions mostly on an emotional level, but also acts as an expression of aggression. The beliefs about sorcery and the power to inflict illness on people is a way of expressing anxieties. The magic

${ }^{60}$ Aparecida Viliaça, "Cultural Change as Body Metamorphosis," in Time and Memory in Indigenous Amazonia: Anthropological Perspectives, eds. Carlos Fausto and Michael Heckenberger (Tallahassee: University Press of Florida, 2007), 170.

${ }^{61}$ Fausto, If God Were a Jaguar, 91.

${ }^{62}$ Viliaça, Cultural Change as Body Metamorphosis, 172.

${ }^{63}$ Malinowski, Magic and Religion, 128. 
used by the shaman to cure illness is governed by their theory of the cause of illness, or cauši. Cauši are evil objects that enter the body and create the illness that the sorcerer intends. Shamans have the role of healer in Mundurucu society, but there is belief that there are no strong sorcerers left. Thus, the society increasingly depends on Western medicine and feels disillusioned about magic. Persecution of sorcerers creates cohesion amongst the other members of the society, but is a self-destructive cathartic for aggression especially among groups that have been ravaged by epidemic disease. Illness contributes to belief in spiritual warfare, and belief that illness is a consequence of sorcery emerges after contact with non-indigenous people, circa 18th-19th century. Daily Subsistence as a Lifestyle

Amazonian indigenous society is deeply interwoven with the natural environment. Many Amazonian tribes are semi-nomadic and depend on fragile ecosystems for daily subsistence. The Kaapor tribe of the Tupi linguistic family live from daily subsistence practices and find all the water, food and medicine they need from the forest and take only what they require at the moment. ${ }^{64}$ Their second chief, Waldermir Kaapor, emphasizes that they do not need packaged goods to survive as Westerners do: "we don't need to carry any food with us because the forest provides everything we need." ${ }^{65}$ Most importantly, they express enjoyment of their lifestyle and the desire to keep it as it is.

Berta Ribeiro's essay entitled "Ecological Consciousness in Amazonia: The Indigenous Experience," uses various case studies of indigenous Amazonian groups to

64 "Our Land," ed. Bill Day (Smiling Zebra Films, 2007) [database on-line]; available from http://www.chicomendes.com/ourlandvideo.html; Internet; accessed 22 January 2009.

${ }^{65}$ Ibid. 
explain that itinerant agricultural practices such as small-plot gardening "prevent exhaustion of the soil and fauna and ... conserve the productivity of the soil and thereby ensure maximum advantage from natural resources." ${ }^{66}$ Amazonian indigenous groups combine agricultural cultivation of domesticated plants such as manioc with hunting, fishing and gathering practices. The main components of their diet include fish, manioc and honey products. ${ }^{67}$ These traditional practices have minimal impact on the surrounding ecosystem because they are based on a varied use of natural resources that allows for the environment to replenish and to complete natural cycles of regeneration. But if their density were greater, these same practices might well be destructive.

Itinerant land cultivation is a prime example of the type of land management indigenous peoples of the Amazon region use that reflects a keen understanding of the sensitivity of local species. While itinerant resource use impacts the environment through slash-and-burn farming, fishing, and hunting, it is done in such a way that allows for species regeneration. Also, subsistence lifestyle involves daily collection of food and, therefore, minimal waste. In fact, the discarded seeds left by a group grow into foodstuff, "the Nukak leave a resource patch behind them when they abandon and relocate camp." ${ }^{16}$ This is a more efficient agricultural land use than Western cattle farming in the region, which clears "10,000 hectares in a single year . . lasts only two years and produces the derisory amount of thirty kilos of beef per hectare. This means that one head

${ }^{66}$ Berta G. Ribeiro, "Ecological Consciousness in Amazonia: The Indigenous Experience," in Ecology and Poverty, eds. Leonardo Boff and Virgil Elizondo. Concilium. 5 (Maryknoll: Orbis, 1995), 22.

${ }^{67}$ Politis, Foragers in the Amazon, 34.

${ }^{68}$ Ibid., 41 . 
of cattle eats the equivalent organic matter to that consumed by an indigenous family, with the added damaging effect of destroying the soil and, as a result, altering the climate and the water system through irrational clearing of virgin forest." ${ }^{69}$ The hunting practices of the Hudpu tribe involve logistic boundaries that leave hunted ground untouched for at least two weeks. ${ }^{70}$

Traditional indigenous treatment of the land in the Brazilian Amazon is not stewardship because it is based on a negotiation between humans and the rest of nature. This means that, while there are limits on foraging, hunting, and horticultural activities, it is not due to an understanding that non-human nature must be managed, but reflects a culture of identification through the vitality of an ecosystem. Destroying the ecosystem would destroy their identity. If there is no source for understanding humans as "stewards" in these traditions, why is the managerial language of "stewardship" and "sustainability" being used by these groups today? I will return to this question after first exploring the "stewardship" model in Christianity.

${ }^{69}$ Ribeiro, Ecological Consciousness, 22.

${ }^{70}$ Politis, Foragers in the Amazon, 34. 


\section{CHAPTER II: TRADITIONAL CHRISTIAN THEMES}

Within the Christian tradition there are a number of different authoritative

sources. Different strands of Christianity sometimes utilize sources not recognized by others, or not given the same weight. However, the Hebrew Bible and the New Testament, known to all Christians as the Holy Bible, comprises an authoritative text that informs all of the Christian tradition. Protestant Christianity has usually approached the Bible as the sole source of revelation, while Catholic Christianity has recognized not only scripture but also the tradition of the church as revelatory.

The main and most generalized understanding of the scriptural tradition begins with what Christian exegesis of the Bible understands to be the $P$ narrative of the creation of the world by God. This is quickly followed by the second, Garden creation story and Fall of humanity from a state of total harmony and grace, which is also known in Christian exegesis as the $\mathrm{J}$ narrative of creation. Over two millennia of relations between God and fallen humanity are covered in Scripture and, for Christians, the end to this long history begins with the incarnation, death and resurrection of Jesus Christ, who ushers in the redemption of mankind.

Jesus is the central figure who inspires faith for Christians that the world and humanity will be restored to the state of grace that God intended for it. Jesus was Jewish, and the ancient Jewish, particularly that found in the Hebrew Bible, concept of the divine and of creation and redemption is embedded in what comes to be known as Christianity. The state of grace in the world is described in the Bible as a world where predators and prey live in peaceful harmony and the world is filled "with the knowledge of the 
LORD." ${ }^{11}$ The Jewish tradition's focus on an immanent God "with us", interpreted through the cosmology of ancient Greece with its focus on eternal forms, develops into the emergence of Christian theology, which eventually provides a notion of salvation theology that leads from creation, fall to redemption in the life and resurrection of Jesus. Jesus' life and ministry provided in the Gospels gives an example of moral living in the world that includes a model of stewardship based on agape, or selfless love. But how do the three key stages of creation, fall, and redemption in the Christian worldview instruct its adherents on how to live properly in our world today?

Christian teachings of creation, fall, and redemption must address the myriad complexities and moral dilemmas humanity faces in the world because this tradition is notably influential in Western society. Christianity has a rich tradition of scriptural exegesis that seeks to inform faith with a praxis that resonates with the message of redemption and restoration. Interestingly enough, while fields such as biblical hermeneutics, Christian ethics, and Christian theology flourish and expand on ecclesial and academic levels, the lived experience of redemption seems almost impossible to many who live in the Christianized West. Suffering, human injustice, violence and ecological crises are prevalent, and the world is in ever-deepening need of the redemption and restoration that Christianity promises.

The current ecological crisis represents a need for reconstructed religious understandings that better inform human interactivity and human relations with nature. Christian ideals of redemption and restoration and the role of humans as stewards of nature are necessary in as far as Christianity remains the dominant paradigmatic

\footnotetext{
${ }^{71}$ Isa. 11:8-10.
} 
framework in Western society. There is no doubt that alongside this new Christian understanding in the West, there is also need for an increased tolerance of religious diversity and the introduction of new symbols into longstanding traditions so that they can better inform humanity about how to live within the rest of the natural world. The ecological crisis is mainly caused by humanity and much of it is irreversible, so the religious discourse that affects society's relationship to nature is very relevant for exploring the problem of environmental degradation and identifying possible solutions. It is also important because ecological degradation is a frequent cause of the suffering of the poor and marginalized citizens of the world.

The deep connection between human suffering, human injustice and ecological disharmony is addressed within the Christian tradition through ideas such as stewardship and agape. ${ }^{72}$ In Christian ethics, the disruption of the natural order God created is triggered by human sin and common depictions of such disobedience include injustice towards the poor and waste of nature:

They trample on the heads of the poor as upon the dust of the ground and deny justice to the oppressed. ${ }^{73}$

The redemption of humanity and the world includes the restoration of justice for humanity as well as the restoration of harmony in the rest of creation. Wisdom texts in the Hebrew Bible represent natural phenomena as educative, and use the metaphor of monarchy to reveal that a just ruler establishes and reigns over an equitable society. Liberation theologians emphasize that the life and ministry of Jesus reveals a preferential

\footnotetext{
${ }^{72}$ Gk. "Selfless love."

${ }^{73}$ Am. 2:7.
} 
option for the poor as well as a basis for struggle to undo hierarchical orderings in the world and usher in the redemption of creation.

Do contemporary theologians present a way for ecumenical and scholarly interpretations to better inform mainstream Christian praxis for human-nature relations? Does the model of human stewardship in society and towards nature represent an appropriate interpretation of Scripture? While still setting humans as "above" nature, stewardship can counter those interpretations within the tradition that understand human difference from the rest of the natural world as indicating human dominion and superiority.

\section{Bestowal of Dominion in the Creation Accounts}

I begin with a brief exegesis of the creation accounts in the Book of Genesis, where God creates land, water, human and non-human beings. In Genesis 1:26-28, we see that humans are made in the image of God and given blessings to procreate and to rule over non-human life and eat of seed and fruit:

Let us make man in our image, after our likeness. They shall rule the fish of the sea, the birds of the sky, the cattle, the whole earth ... God blessed them and said to them, "Be fertile and increase, fill the earth and master it; and rule the fish of the sea, the birds of the sky, and all the living things that creep on the earth.

Close study of the Hebrew root word $\mathrm{r}-\mathrm{d}-\mathrm{h}$, translated as "rule" in Gen 1:26 and 1:28 and $\mathrm{k}-\mathrm{b}-\mathrm{sh}$, translated as "master" in Gen 1:28 reveals that both the literal and metaphorical meanings imply that humans were given a superior role over nature and earth creatures by God. ${ }^{74}$ Although this command is commonly translated as "dominion" in religious discourse, the translation of the word coincides with the literal meaning of

${ }^{74}$ William Lee Holladay, A Concise Hebrew and Aramaic Lexicon of the Old Testament: Based upon the Lexical Work of Ludwig Koehler and Walter Baumgartner (Grand Rapids: William B. Eerdmans, 1972). 
$\mathrm{r}-\mathrm{d}-\mathrm{h}$, which is "to tread," while the term "dominion" refers to the metaphorical meaning of $\mathrm{r}-\mathrm{d}-\mathrm{h}$, to "rule" or to "govern." In certain contexts, $\mathrm{k}-\mathrm{b}-\mathrm{sh}$ means "violate" or "rape" and in others it means, "conquer," as in, a people. So, the translation of $k-b-s h$ as "subdue" is derived from a metaphorical reading of the word.

Genesis 1:26-28 is central to the Christian interpretation of the divinely ordained relationship between God, humans and non-humans. Two ideations of the proper relationship emerge from this passage. One interprets the passage as God giving humans dominion over creation and the other interprets $\mathrm{r}-\mathrm{d}-\mathrm{h}$ metaphorically so that God appoints humans to rule as stewards. Either interpretation is anthropocentric because they both instrumentalize non-human creation, but the latter implies a component of human responsibility and accountability. Humans are considered to be superior to non-human creation because they are created in the image of God (imago Dei); this is the personalized characteristic of humans that Christian interpretation generally sees as exclusive among all of creation. This personal aspect thought to be present in humans alone develops into a hierarchical understanding of creation within the Christian tradition.

\section{Order in the Creation Accounts}

The differentiation of humans, non-humans, and the "earth" is understood as God's conscious creation of a natural order, or law. For Protestant Christianity, the natural order is either fallen and unredeemed, or at the very least, unredeemed humanity is not capable of recognizing any God-given order in creation. In Catholic theology, the moral teaching known as natural law is derived from this understanding of God's ordering of creation combined with classical Greek ideas such as Plato's Forms and Aristotelian teleology. Though prototypes of natural law can be found in Augustine's Neo-platonic 
understanding of creation and in his understanding of the "two books," Nature and Scripture, the most comprehensive theology of natural law was developed by St. Thomas Aquinas.

Aquinas argued that God transcends the order of creation. While also being in all of creation, "God established the order of nature" ${ }^{15}$ and "God is above all things by the excellence of His nature; nevertheless, $\mathrm{He}$ is in all things as the cause of the being of all things. ${ }^{76}$ Christian ethicist Michael C. Northcott argues that Aquinas' natural law theory does not give evidence of a teleological God-essence in all things. Indeed, Aquinas insists that there is a hierarchy (the Neoplatonic "Great Chain of Being") within creation:

In natural things species seem to be arranged in degrees; as the mixed things are more perfect than the elements, and plants than minerals, and animals than plants, and men than other animals; and in each of these one species is more perfect than others. ... For the universe would not be perfect if only one grade of goodness were found in things. ${ }^{77}$

The very order of things created by God shows the unity of the world. For this world is called one by the unity of order, whereby some things are ordered to others. But whatever things come from God, have relation of order to each other, and to God ... ${ }^{78}$

Aquinas' natural law theory, which will be discussed more below, is central for Catholic ethics, and so is the understanding that, while God created everything, humans are above non-human beings and the earth itself. Aquinas is only central for Catholics. Protestants deny the existence of a natural law, because in Protestant ethics, scripture is the only

${ }^{75}$ Summa Theologica, 1, 105, 5, as cited in A Summa of the Summa: The Essential Philosophical Passages of St. Thomas Aquinas' Summa Theologica, ed., Peter Kreeft (San Francisco: Ignatius Press, 1990), 237.

${ }^{76}$ Ibid., I, 8, I., 102.

${ }^{77}$ Ibid., I, 47, 2., 206.

${ }^{78}$ Ibid., I, 47, 3., 207. 
revelation, and nature is fallen and not redeemed. However, this does not mean that "nature" has been totally absent from Protestant thought. Whereas in the Catholic tradition a much more "sacramental" understanding of nature holds in which God is present both in the book of nature and in the book of scripture, in the protestant tradition, God's covenant with humans, both individual and collectively, can also be and has been extended to the rest of creation.

\section{Covenantal Agreement}

The covenantal relationship that develops in the Hebrew tradition implies that the original order of creation is disrupted by human sin, and that God consequently makes agreements with humans by affecting the quality of relations between humans and the rest of nature. The basic covenant between God and humans is that God promises a blessing in exchange for humans' strict obedience and worship. In Christian theology, the covenantal relationship begins with the Hebrew Bible, ${ }^{79}$ continues with the Christian Testament, and is completed with the incarnation of Jesus Christ, where the Church is the living body of Christ in the world. ${ }^{80}$ The Hebrew Bible provides the framework of

${ }^{79}$ According to Jewish tradition, the Hebrew Bible is divided into the Torah (Law of Moses), Nevi'im (Prophets), and Ketuvim (Writings). The Torah is comprised of the first five books of the Bible- Genesis, Exodus, Leviticus, Numbers and Deuteronomy. The main content of the Torah deals with creation, laws, the establishment of the first covenants, the lives of the patriarchs, the construction of the Tabernacle and the narrative of the Israelites exodus and settlement. Nevi'im includes the history of the Israelites, land ownership, establishment of Israel's ancient monarchs, and prophecies (including messianic prophecy). Ketuvim includes the wisdom texts, liturgical and poetic texts, the Babylonian period and the reestablishment of Jerusalem.

${ }^{80}$ There is debate as to whether "creation theology" is subsumed under "salvation theology," and can therefore only be seen in terms of salvation (explicitly anthropocentric argument) or whether creation theology is important in its own right (less anthropocentric argument). This difference has implications for the stewardship model. See Von Rad, Old Testament Theology, $136 \mathrm{ff}$. and Paul von Dyk, A Brief History of Creation, p. 123. 
covenantal accord between God and humanity and also illustrates that the quality of human stewardship over the rest of creation expresses the quality of obedience to God. Obedience and proper stewardship is characterized by God's bestowal of prosperity, fertile land and desirable climate. Disobedience and improper stewardship results in curses from God in the form of taking land away, disease, natural disaster, famine, and exile.

A covenant in the strict sense of the term has not been established when humans are given their first role in the $J$ creation story in Genesis 2:8-15. Here, God plants the Garden of Eden and gives the primordial human, 'adam, ${ }^{81}$ the job of gardener in this plentiful place. The Garden becomes a prototypical home established for humans, a dwelling place where the order of creation is harmonious. In the garden, 'adam gives names to all of the non-human creatures. This is an example used to buttress the traditional Christian interpretation that humans are superior to the rest of creation. A hierarchy of ordered creation establishes that each superior part of creation is responsible for the creation below it, but God acts upon all of the orders. For example, God must establish fertility in order to complete creation:

When no plant of the field was yet in the earth and no herb of the field had yet sprung up- for the LORD God had not caused it to rain upon the earth ... 82 The axioms established here that later become part of covenantal relationship are that God cares for ordered creation and provides for it accordingly and that creation is made to work according to a natural order. This order is commonly interpreted as hierarchical;

${ }^{81}$ I provide the Hebrew word that is generally translated as 'man' because it literally means 'earth-creature.'

${ }^{82}$ Gen. 2:5 
however, God is at the background of the order and acts on any level of creation at any time.

The Jawhist creation account takes a sudden turn away from peaceful and bountiful ordered hierarchy when the first humans, Adam and Eve, eat the forbidden fruit and are cast out of the Garden of Eden. The consequences of this transgression affect the land as well as humans:

Cursed be the ground because of you;

By toil shall you eat of it all the days of your life:

Thorns and thistles shall it sprout for you.

But your food shall be the grasses of the field;

By the sweat of your brow

Shall you get bread to eat,

Until you return to the ground. ${ }^{83}$

The well being of humanity will forever be linked to its relationship with the land. Here is the first break in God's created order, whereby fertility is negatively affected as a consequence of Adam and Eve's transgression. The original natural order, one where "God made to grow every tree that is pleasant to the sight and good for food" ${ }^{84}$ is taken from humanity and in its place the relationship between humans and the food they derive from the land is marked by hardened labor and uncertain yield. As William Dyrness points out, "The implication is simply that there is now something wrong with the order of things that will show itself in ecological misfortunes." ${ }^{15}$

${ }^{83}$ Gen. 2:17-19.

${ }^{84}$ Gen. 1:9.

${ }^{85}$ William Dyrness, "Stewardship of the Earth in the Old Testament," in Tending the Garden: Essays on the Gospel and the Earth, ed. Wesley Ganrberg-Michaelson (Grand Rapids: William B. Eerdmans, 1987), 55. 
Two basic characteristics of the relationship between God and humans are revealed in these passages. First, God has personal dealings with humans that prescribe and proscribe appropriate behavior while giving humans free will. The rest of ordered creation is under the direct command of God and lacks free will. Humans' ability to disrupt order gives them agency that is negotiated with God. Second, natural order includes human use of land for food cultivation and the quality of subsistence changes depending on God's reaction to human choice. Divine reactions through nature affect the quality of the land as fertile or barren, easy or arduous to cultivate. Human consumption of food is related to laboring the land, but the introduction of hard work comes only with the disruption of natural order; the Garden is characterized as abundant, beautiful, and harmonious. The interaction of free will and divine decree exclusively characterizes this relationship.

The generations after Adam and Eve fell into sin as well, and God demonstrated personal discontent with this by deciding to destroy the creation. In Genesis 6:14-16, God commands Noah to build an ark and take upon it his family and beings of each species, with the promise that God will establish a covenant with Noah, who is righteous in his generation. ${ }^{86}$ The ensuing flood destroys the created world; once again we see the land negatively affected because of a fall-out between God and humans. In Genesis chapter 9 , the first covenantal relationship provides a bilateral agreement without "any action on the side of the human partners," ${ }^{87}$ though it is preceded by Noah's sacrifice. Humans are to

${ }^{86}$ Gen. 6:18; 7:1.

${ }^{87}$ This is the first explicit act of species conservation in the Jewish and Christian traditions. See Margot Kässmann, "Covenant, Praise, and Justice in Creation: Five Bible 
obey new laws concerning food consumption and sacrifice of animals. God offers a rainbow as the first sign of the first covenant. This sign is a natural phenomenon that appears in nature but does not involve human activity. This aspect of covenantal sign changes as ensuing acts of human sin result in an ever-widening distance between God and humanity and an ever-increasing distance from the natural order of the Garden, and an increasing need for human involvement in the establishment of covenant with God.

Two interesting additions to the relations between God, humans and non-human nature occur at this point in the narrative of Noah and the Flood. One is that God's blessing regarding human relations to non-humans changes from Genesis 1:26-28 to a relationship that is no longer characterized only by $\mathrm{r}-\mathrm{d}-\mathrm{h}$ (rule) but also by fear:

Be fruitful and multiply, and fill the earth. The fear and dread of you shall rest on every animal of the earth, and on every bird of the air, on everything that creeps on the ground, and on all the fish of the sea; into your hand they are delivered. Every moving thing that lives shall be food for you; and just as I gave you the green plants, I give you everything. ${ }^{88}$

The other is that, while God bestows humans with an intensified role as rulers over nature, the covenant God makes clearly includes all living things. So, while the status of non-human creatures is lowered to include them being eligible as food for humans and fearful of humans, non-human creation is also given explicit importance as members of the first covenant. The covenant tradition that develops continues to emphasize fertility, the quality of human/nature relationship, and God as the ultimate force that guides nature.

Studies," in Ecotheology: Voices from South and North, ed. David G. Hallman (Maryknoll: Orbis, 1994), 30.

${ }^{88}$ Gen. 9:1-3. 
The covenantal nature of divine relationship with humans continues with the divine promises of ownership of land and progeny bestowed to Abraham:

I will make of you a great nation, and I will bless you, and make your name great, so that you will be a blessing. ${ }^{89}$

Look toward heaven and count the stars ... So shall your descendants be. ${ }^{90}$

To your descendants I will give this land. ${ }^{91}$

Covenantal promises now include demarcated land and progeny and require a blood sacrifice of circumcision as a sign. Contingent upon devotion and obedience, God blesses humanity with fertile land and descendants. The understanding in Christian ethics is that bestowals are gifts that should not be worshipped, for "Treating nature as divine gift rather than as an object of worship is inherent in the First Commandment to abstain from idolatry of the natural order and instead to worship God alone." ${ }^{92}$ However, fertility and prosperity are signs of divine good will and that obedience to God includes regard for non-human nature's well being as well as regard for future generations. ${ }^{93}$ Metaphor of Rule: Steward as Just Monarch

The blessing of becoming a great nation, with demarcated land, introduces the theme of sovereignty to the tradition of covenant, thereby adding to both interpretations of dominion and stewardship present in the Christian tradition. The laws given in the first

${ }^{89}$ Gen. 12:2.

${ }^{90}$ Gen. 15:5.

${ }^{91}$ Gen. 15:18.

${ }^{92}$ Michael S. Northcott, The Environment and Christian Ethics (New York, Cambridge, 1996), 170.

${ }^{93}$ Ibid., 129. 
section of the Hebrew Bible include proper agricultural practice and restrictions on the destructive treatment of land. For example excessive reaping of harvest is prohibited ${ }^{94}$ and, in Leviticus 25:2-4, the law of sabbatical year for the land is established:

When you enter the land that I am giving you, the land shall observe a Sabbath for the LORD. Six years shall you sow your field ... but in the seventh year there shall be a Sabbath of complete rest for the land, a Sabbath for the LORD.

Destruction of natural resources when occupying foreign land is also prohibited, "You must not destroy its trees by wielding an ax against them. ... Are trees in the field human beings that they should come under siege from you?"195

But the land Israel enters is already settled, which complicates the issue of stewardship beyond a simple human-nature relationship to include inter-human relations as well. Settled lands are taken by force and human violence pervades the settlement of the Promised Land and the expansion of God's chosen people. Women and children are stolen away as booty and enslavement is normative in this process of conquest. Here, a violent and repressive regime of the powerful over the powerless supports the interpretation of human dominion over nature as well as over conquered peoples. This is just an ambiguity that exists within scripture, but it seems that there is much more weight given to justice toward the "other" rather than enslavement and domination over the other. A tension regarding oppression of the Other emerges, through God's expulsion of the Israelites from Israel and into captivity. Captivity is the experience Israelites identified as God forsaking them because they did not uphold the covenantal agreement.

\footnotetext{
${ }^{94}$ Lev. 19:9; 23:22; Deut. 24:19-20.

${ }^{95}$ Deut. 20:19.
} 
As Israel expands and becomes a nation, the tradition of covenant develops and human obeisance is often depicted using the metaphor of monarchy. A just ruler of Israel is one that serves his or her subjects while "never exalting himself above other members of the community nor turning aside from the commandment ... " of God. ${ }^{96}$ This combination of obeisance, rule and humility is meant to temper hierarchical relations between humans and between humanity and non-human nature so that justice coincides with prosperity and well being. Beneficent rulers convey the proper characteristics of stewardship, which involve caring for all members of society and managing resources so that they provide for everyone.

Laws and restrictions regarding land use and human relations abound in covenantal agreements. The complex involving divine blessings or curses on the land and people relates to equitable society as well as proper land use. Societal justice includes fulfillment of basic needs of food, clothing and shelter as well as a unitary code of law applicable to all persons, "The biblical basis for justice ... starts with the establishment of a covenant, one of whose cardinal features is righteousness." ${ }^{97}$ The righteous monarch reveals the deep connection between social and ecological well being. Rules ensure that the disenfranchised person, the lost animal, or untended land will be included in the blessings promised by covenant. One of the main tools used at this point in the establishment of Israel through covenant is the understanding that freedom from enslavement in Egypt requires that they act in good conscience in their new community. Blessings of the covenant are incentives to suppress negative impulses toward greed,

${ }^{96}$ Deut. 17:20.

${ }^{97}$ Ex. 22:21-24. James B. Martin-Schramm and Robert L. Stivers. Christian Environmental Ethics: A Case Method Approach (Maryknoll: Orbis, 2003), 37. 
violence, and oppression and to actively choose the harmony God first designed for creation. The metaphor of a just ruler is based on a pre-lapsarian divine Creator, who loves creation and serves it.

The environment remains central throughout the establishment and fulfillment or breaking of covenants. Christian ethicists argue that the monarchical model of the Hebrew Bible is one that does not draw separation between God and the created world. This understanding of human dominion notes various important points regarding the covenantal bestowal of land and lower orders of nature to humans. The centrality of piety and righteousness among individuals selected for divine blessings depicts a form of mastering the land and people so that justice and abundance and equity prevail, so that "morality, response to God, and fertility are interrelated." ${ }^{\text {98 }}$ Instructions for how to rule the creation are given through the laws and covenants, and disobedience results in barrenness, exile, and injustice. The consequences for disobedience involve climatological catastrophe, disease, and physical displacement. ${ }^{99}$ The power to bless or curse humanity places God at the backdrop of all creation, using it in ways that indicate the ethical quality of human behavior.

The prophetic books of the Hebrew Bible illustrate that divine punishment through ecological disaster ensues when humans do not rule creation righteously, but are consumed by greed, wastefulness, and social injustice:

They trample on the heads of the poor as upon the dust of the ground and deny justice to the oppressed....

I will tear down the winter house along with the summer house; the houses adorned with ivory will be destroyed. ...

${ }^{98}$ Dyrness, Stewardship of Earth, 57.

${ }^{99}$ e.g. Deut. 28:15-68. 
I also withheld rain from you. ...

Many times I struck your gardens and vineyards, I struck them with blight and mildew....

I sent plagues among you. ${ }^{100}$

God's blessings and rules become ever more complex as humanity grows. One of the new aspects to the covenantal agreement we see in the metaphor of monarchy is that interhuman relations and human-nature relations form a web of human relationship to God. But the prophets make clear that the order God reestablishes through covenant has ecological as well as human consequences.

\section{Wisdom Tradition}

Wisdom texts in the Hebrew tradition serve to illustrate the complex relationship that humans have with their surrounding environment and show that there is a great deal of knowledge to be gained from natural cycles and phenomena. Descriptions of natural phenomena as well as the behavior of non-human creatures provides moral instruction as well as simple valuation of the wonder of God's creation. The Hebrew term tahbuloth, or "art of steering," refers to experiential knowledge provided by wisdom literature based on the understanding that God pervades in the workings of the natural order. ${ }^{101}$ King Solomon is the prototype of a secular leader that rules through knowledge of the environment. $^{102}$ Also, the nature poems found in the Psalms, God's speech in Job 38-41 and the sayings in Proverbs illustrate that natural phenomena in the created order reveal

${ }^{100}$ Am. 2:7; 3:15; 4:7, 9, 10, quoted from Dyrness, Stewardship of Earth, 60.

${ }^{101}$ Robert K. Johnston, "Wisdom Literature and its Contribution to a Biblical Environmental Ethic," in Tending the Garden: Essays on the Gospel and the Earth, ed. Wesley Ganrberg-Michaelson (Grand Rapids: William B. Eerdmans, 1987), 68.

102 Ibid., 69. 
that God's creation is harmonious because it is thoughtful. The wisdom texts also reveal the extent to which God may act through natural phenomena to check any human ambition, whether through natural disaster, through sheer magnitude, or through mysteries of natural phenomena.

\section{Jesus Christ: Redeemer and Restorer}

Classical Christian theology is based on the New Testament account of the birth, life and death of Jesus as documented in the Gospels. ${ }^{103}$ Early Church activities of Jesus' disciples, the establishment of early churches, and interpretations of Jesus' teachings are found in Acts, the Epistles of Saint Paul and other letters such as Jude and Revelations. The life and ministry of Jesus provides many accounts of Jesus healing and working miracles for people normally cast aside in Jewish society because of an illness, impurity or morally inferior position. Jesus disregards many ongoing debates regarding halakah, Jewish law, and focuses instead on a message of inclusive community, inner conscience and intention, and eschatological hope. From this scriptural foundation, a system of theological exegesis emerges.

A brief survey of Jesus' life and ministry indicates the model of human-nature relations he advocated. Jesus reinterpreted Hebrew tradition in light of the social injustices of his time, making him the exemplar steward in Christian history. The moral lessons that emerge from Jesus' parables describe the kingdom, or basileia in Greek, of

${ }^{103}$ The Synoptic Gospels, Matthew, Mark, and Luke, deal with the life and ministry of Jesus. The Gospel of John focuses on Jesus' life and ministry in Judea. 
God that Jesus ushers in. ${ }^{104}$ The basileia is the reordered world ruled by justice, egalitarianism, ${ }^{105}$ and humility that had been lost by sin and human injustice.

The parable of the Sower and the Seed uses the metaphor of God's people as the soil in which the gospel is planted in different ways. ${ }^{106}$ God is the landlord and steward of the fertile field; seeds that fall away do not bear fruit and the "good soil" represents people who listen to the word of God and follow it. Some people hear God but are beguiled by evil, others are apostates whose belief is too shallow to endure, and still others hear the word but dismiss it and choose a life of greed and worldly concerns. This parable emphasizes that fertile land and proper sowing of seeds is a sign of the divine as steward of humanity. The Hebrew tradition of relating God's providence to seeds continues through from the Hebrew tradition in the teaching of Jesus. The agrarian field is a key metaphor Jesus used to explain that humanity is dependent on nature as God is dependent on humanity. This teaching is similar to the moral lessons in the wisdom texts in the Hebrew Bible, where a properly sown seed produces good fruit. ${ }^{107}$

104 Christianity begins as an "inner-Jewish renewal movement that presented an alternative option to the patriarchal structures rather than an oppositional formation rejecting the values and praxis of Judaism." See Elisabeth Schüssler-Fiorenza, In Memory of Her: A Feminist Theological Reconstruction of Christian Origins (New York: Crossroad, 1983), 107.

${ }^{105}$ I mean to say here that diverse people are unified in the kingdom of heaven, as per Matt 13:47, "the kingdom of heaven is like a net that was let down into the lake and caught all kinds of fish."

${ }^{106}$ Mk. 4:2-20; Matt. 13:18-23; Lk. 8:11-15.

107 The metaphor of sowing the gospel as seed is used to give moral instruction and is common to the Hebrew wisdom texts. e.g. Prov. 11:18, "he who sows righteousness reaps a pure reward." 
The parable of the feeding of the 5,000 is common to all four Gospels. ${ }^{108}$ The miracle in this parable is that multitudes were fed with five loaves of bread and two fish. The practical aspect of this event reveals the moral of this teaching, that when Jesus and his disciples shared their food, everyone shared their food and there was more than enough for all to eat. Jesus' disciples hesitated to share what little food they had, but Jesus showed them how to teach by providing an example of the proper behavior. As a role model, Jesus' intention and action make him an exemplary of social stewardship and righteous manager of resources. Jesus emphasizes that sustenance for all is an aspect of the reordered basileia and makes an explicit connection between society and food resources. Sharing the providence of the land, food, is an integral aspect of charity and a means to reorder human relations with the original creation. This is a social teaching that clearly refers to the intersection between social justice and the use of natural resources. Another method of instruction that Jesus employed which involved food is in the metaphor provided by the last meal he shares with his disciples. This communal meal is ritualized in the sacrament of Eucharist. ${ }^{109}$ The Eucharist meal brings together the community of disciples, the very first church, to give thanks to God through the sharing of wine and bread. Jesus refers to the wine and bread as his blood and body, willingly given up for the sake of humankind. While Jewish praxis had come to be characterized during the life of Jesus by the institution of cultic temple worship by the priestly class, "his movement did not observe these purity regulations and even shared their meals with

${ }^{108}$ Mk. 6:32-44; Matt. 14:13-21; Lk 9:10-17; Jn. 6: 1-14.

${ }^{109}$ Mk. 14:22-25; Mtt. 26:26-29; Lk 22:15-20. 
'sinners."' 110 Jesus reinterprets the cultic ritual meal familiar to Judaism anti-

hierarchically so it includes all members of society. Jesus' teaching connects the importance of sustenance with the need for social equality and community.

Jesus emphasizes community in his relationship to his disciples and to the masses that come to him for physical healing. For Jesus, the act of healing others meant taking on the suffering of others, so that restoration of God's creation involves the healing of the body as well as the spirit. It means loving one another and treating others as we want to be treated, not in hierarchical relations where the powerlessness is the lot for most of society. This is another aspect of the stewardship model that develops out of the Hebrew tradition, as we saw above in the use of righteous monarch as steward. SchüsslerFiorenza clarifies the importance of healing all members of society in order to realize the basileia of God, "the reality of the basileia spells not primarily holiness but wholeness . . ."111 Jesus heals people of moral as well as physical ailments; the poor, the sinful, tax collectors, prostitutes, cripples and lepers are all welcome to the community he institutes. ${ }^{112}$ The morally sinful often do the job that allows them to survive at the expense of their reputation and are therefore marginalized by their need before they are ostracized by their occupation.

${ }^{110}$ Schüssler-Fiorenza, In Memory of Her, 119.

${ }^{111}$ Ibid.,120.

112 "Throughout late antiquity tax collectors were likened to robbers and thieves, and treated with contempt for their coarseness. Their harassment and extortion were notorious." Schüssler-Fiorenza, In Memory of Her, 128. 
In order to overturn the norms of society that would marginalize these people, Jesus teaches that the last will come first in the basileia of God. ${ }^{113}$ The Sermon on the Mount is an example of the Hebrew tradition in Jesus' teaching that emphasizes the reordering of relations according to divine will. Jesus emphasizes that cultic worship alone does not express what is in a human's heart and that it is intention, first and foremost, that qualifies a deed as good or evil. Schüssler-Fiorenza refers to this radical message against the hierarchical model of society as an "eschatological reversal" that characterizes the Jesus movement within the larger Jewish tradition. ${ }^{114}$ Jesus recalls Hebrew wisdom texts as well as the warnings of the prophets against greed, for the "meek" will inherit the earth. ${ }^{115}$ The reversals that Jesus introduces as restorative are important to note because they are challenging and do not integrate into the status quo relationship of hegemony of the few over the masses, "the praxis of Jesus and his disciples offended the religious sensibilities not only of their fellow Jews but also of later Christians." 116

According to Christianity, God's greatest act of integration in creation is accomplished through the Incarnation of Christ. God takes on a human body and lives among a society rife with discord and injustice to redeem the deeply disordered creation. Christian environmental ethicists insist that, while God is immanent in all of creation, the Incarnation is pivotal in reordering creation because humans alone "live in self-conscious

\footnotetext{
${ }^{113}$ Mk. 10:31; Mtt. 19:30; Lk. 13:30.

${ }^{114}$ Schüssler-Fiorenza, In Memory of Her, 123.

${ }^{115}$ Matt. 5:5.

${ }^{116}$ Schüssler-Fiorenza, In Memory of Her, 130.
} 
response and moral obligation to the source of being that is God." ${ }^{117}$ The life and teachings of Jesus Christ are rightly based on the ethics of: including all members of society in community, mutual relationships that undermine hierarchical distinction, and redemption found through love and sharing. Such an understanding of Christian ethics is justified because it favors using a stewardship model to emphasize the quality of human care for the rest of nature. Unfortunately, these aspects of Jesus' example are subsumed in the institution of the Church (i.e. a hierarchy) that obscures these qualities of egalitarianism and mutuality, and we see the Christian tradition tending towards a worldview that differentiates levels of being in hierarchical terms. Aquinas, Natural Law, and The Scientific Revolution

One of the most influential theologians whose work is relevant to our discussion of the Christian understanding of human-nature relations is Saint Thomas Aquinas (12251274). Aquinas' theology has been basic to Roman Catholic thought for the last two centuries. Aquinas developed what is known as natural law ethics, which sees God in all things, and all things ordered by God. ${ }^{118}$ Aquinas incorporated classical Greek ideations of a qualitative distinction between spirit and matter that reinforced hierarchical interpretations of the natural order, thus placing physical being unquestionably inferior to the transcendent spirit. Aquinas' theology is less influential among Protestants because "it was Neoplatonism with its idea of the Great Chain of Being, rather than the Bible, that

${ }^{117}$ Fr. Richard John Neuhaus, in "God's Earth: A Call for Environmental Stewardship," Films for the Arts and Sciences, series 7576 (Princeton: Films for the Arts and Sciences, 2004).

${ }^{118}$ See section on exegesis in the Book of Genesis. 
formed the philosophical basis." ${ }^{119}$ In a hierarchical view of reality "God, who is pure spirit, is at the apex of this hierarchy, while non-spiritual beings, which include plants, animals, and inanimate objects, are at its bottom. The hierarchy is graded according to the extent of the spiritual nature of beings . . .Humans, as embodied spirits . . . are below God and the angels but above all other living beings." ${ }^{120}$ But Aquinas also emphasizes that every being is a manifestation of God's goodness, even as it serves the orders above it. ${ }^{121}$ Aquinas says that, "The whole of material nature exists for man, inasmuch as he is a rational animal." ${ }^{122}$

Two beliefs inherent in natural law theory - that a transcendent God created a natural, orderly world and that humans are ordered above the rest of creationcontributed to the scientific revolution. Modern science assumes that the world is rational and can be experimented on because humans are superior and also because God transcends nature and, therefore, nature is not sacred. A mechanical view of the universe removes God from the worldview by abstracting activity in the world as derived from the creator/mechanic setting the machine of creation in motion rather than a creation based on the infusion of God in the whole of creation. This mechanical understanding dismisses ethical qualifiers inherent in a stewardship model derived from Scripture, such

${ }^{119}$ David Kinsley, "Christianity as Ecologically Harmful," in This Sacred Earth: Religion, Nature, Environment, ed., Roger S. Gottlieb (New York: Routledge, 1996), 108.

${ }^{120} \mathrm{Ibid}$.

121 Ibid.

122 Ibid. 
as conscience, good will, and social justice, and accepts the human instrumentalization of nature.

Aquinas' theology of salvation implies spiritual transcendence over material existence, and "leaves the less-perfect world of material creation and the lower creatures behind ... animals are not capable of renewal and perfection, as human beings are." 123 This distinction is complicated by Aquinas' belief that God's essence is in all things, which does not account for the existence of evil in the world or the understanding that human sin has disrupted the original order of creation so that it includes predation, killing, suffering and iniquity. Perhaps Aquinas implicitly deals with this flaw in human character by insisting that the inherent goodness in creation must be exemplified in human conduct, "Only a rational person, and a person who begins to experience such virtues as prudence, justice, temperance, and love, can know fully that this fulfillment is the result of pursuing the good." 124

Another important aspect of Aquinas' natural theology on the role of human stewardship is that creation is ordered to meet the needs of all creation. This teaching becomes critical for Catholic social teaching on private property, which is sanctioned if and only if it benefits all:

Man's greatest competence is to use and manage the world's resources. Now in regard to this, no man is entitled to manage things entirely for himself, he must do so in the interests of all, so that he is ready to share with others in case of necessity. ${ }^{125}$

${ }^{123}$ Ibid.

${ }^{124}$ Northcott, Christian Ethics, 241.

${ }^{125}$ Summa Theologiae 2a2ae, 66:2. 
Private property is not an aspect of natural law but is supported by the rights based on natural law. These concepts of ownership and management of land and of perceiving nature as "resources," support the current model of stewardship because they inform the correct interaction that humans should have with nature is one that objectifies it in terms of human interests.

A notable shift occurs in the Western European tradition from the teachings of Aquinas in the late 13th century to the scientific revolution, and the Protestant Reformation, as well as the era of European Conquest of the "New World" beginning in the mid-16th century. Aquinas' understanding of the hierarchical ordering of nature paved the way for a mechanical Western ideology, but his own model depicted a cosmos animated by the soul. The influence of the Greeks, and especially Aristotelian concepts of demonstration as evidence of rational truth, culminated in European empiricism with the birth of the scientific revolution in the mid-sixteenth century. This major shift was characterized by natural philosophy, which tended toward adherence to rational thought, observation, and experimentation rather than revelation and tradition per se. Also, the Copernican model of a heliocentric universe challenged the Christian worldview that placed humans and the world at the center of creation. Cartesian thought further enabled a distinction between humans and the world by suggesting that all value and knowledge exist in the cogito (found only in humans).

Despite this increasing contrast developing between humans and the rest of nature, the agrarian milieu in which the Church grew and developed during the medieval period was still characterized by a common societal dependence on natural phenomena such as climate and disease, which translated into the understanding that God acts 
through nature for the well being or demise of humanity. This dependence is nuanced by the different degrees of dependence of members of society. The small, literate elite, the growing monastic population (also literate) and the poor illiterate masses had different relationships with the source of their sustenance. For example, elites and clergy did not share their bedroom with a cow during cold winter nights as peasantry did. Perhaps the lower classes felt more akin with the animals they worked in close contact with. However, in general, non-human creation in the medieval period is generally viewed as instrumental and lacking the imago dei.

Medieval Europe was more concerned with what is referred to as "salvation theology" so that the flourishing or demise of nature was a sign to humans from the omnipotent God of their own salvation or doom. The distinction between spirit and matter percolated into society during the medieval period, which is represented in Aquinas' theory of natural order, which supports a humanocentric understanding of humans as the center of God's creation and plan. The Great Chain of Being, beginning with the simplest form of life, peaks in the human, which is the reason for the entire creation. This model of thinking in terms of salvation theology because increasingly dualistic, Christ's Resurrection came to represent spiritual fulfillment as release from physical embodiment rather than the divine example that embodiment is the greatest means for acting in relation to the rest of God's creation.

With the advent of Western science, the Christian doctrine of the spirit/body distinction increasingly dominated any naturalistic understanding of God's existence in nature and eventually led to the understanding that humans, the only beings created in the image of God, were the only aspect of creation containing the spirit of God. The era of 
Europe's conquest of the Americas (1550-1900) contributed largely to the interpretation of proper human-nature relations in terms of dominion, where subduing nature and applying all technological advances to this end would reflect God's greater plan. That is to say that the colonists perceived themselves as guardians of the natives and as responsible for their conversion to Christianity. This need to evangelize the world was in keeping with medieval Europe's characteristic fear of damnation, which, together with the teaching that there was no salvation outside the Church, meant all non-Christian lands and peoples were in dire need of conversion. The act of Conquest combined elements of religious ideology with a pragmatic drive towards economic gain; during this era money became the dominant medium for exchange. ${ }^{126}$ The understanding of God's benevolence took on an economic aspect through the Conquest, and the subjugation, exploration and exploitation of nature (and "natural" people) was justified by this skewed interpretation.

Peter Harrison argues that dominion passages in the Hebrew Bible were interpreted figuratively until the Protestant Reformation and the development of Western science in the 16th century. A scientific and Christian explication of creation by a transcendent God was interwoven with the classical Greek understanding that the distance between God and creation was due to the qualitative distinction between spirit and matter. God, a purely spiritual being, was removed from the physical realm, and humans, having some spiritual capacity as well as physical embodiment, were considered superior to the rest of creation that was deemed purely physical.

According to Harrison, medieval Europe understood nature metaphorically as the polar opposite of superior spirit and, thus, aligned with inferior human instincts and

${ }^{126}$ Ralph Keen, The Christian Tradition (Upper Saddle River: Prentice Hall, 2004),166. 
drives that need to be tamed or suppressed. The social context of this belief must be understood in terms of the deep dependence they felt on the land for their daily sustenance. Reliance on climate and agricultural yield coincided with the belief that these phenomena were in God's control, and that humans were the central reason for the existence of the world. So, God acted through nature on behalf of humans and as a response to human piety or lack thereof. Nevertheless, Harrison's argument sheds light on the ideological shift that this dualistic understanding of humans and nature took as society became more informed by the advent of literacy and science.

The pre-Reformation status quo of agrarian dependence on the land in medieval Europe indicates that the metaphor of human stewardship, while not literally derived from Scripture, may have informed their treatment of the land. Understandings of how to not decimate a natural resource and how to allow for natural cycles to work in humanity's favor coincided with the need for sustenance. Furthermore, the medieval worldview of fearing a distant and almighty God indicates that at the backdrop of human ownership and use of land was the divine, the ultimate force determining success or failure in any worldly situation. The medieval dependence on the land also translated into their conception of management involving the future yield of land.

\section{Conquest Ideology}

"Just when Europeans were revisiting their notion of nature, they were also discovering an astonishing ... explosion of botanical and zoological knowledge." 127 Advances in nautical and other technologies and a harsh history of famines and plagues in medieval Europe propelled the 16th century movement to find and conquer foreign

${ }^{127}$ Davis, Early Modern Protestantism, 120. 
lands. The first colonies were based largely on economic exploits such as mineral extraction and farming. ${ }^{128}$ Shortly after the Conquest began, Dominican and Jesuit missionaries were sent out to convert indigenous people and ensure colonists would remain loyal to the Church. Historian Ross Hassig asserts that "religion provided justification for war but ... the Conquest found its cause in the more pragmatic matters of wealth, power, and privilege." 129

The new scientific movement during the Conquest era was heralded by Francis Bacon (1561-1626) who saw science as a means to "alleviate the consequences of the Fall and to improve the human condition." 130 The increase in raw data about the natural world led European intellects such as Bacon, Isaac Newton, et al., to increase emphasis on measuring, collecting, and experimenting with nature. Foreign lands were assumed to need the same type of management used in European agriculture and studies of the exotic were aimed at encapsulating the presence of newly "discovered" species by testing them in laboratories and showcasing them in gardens and botanical museums. Scientific archives and a burgeoning genre of scientifically-based literature about the exotic life forms found in newly conquered regions contributed to the West's self-identification as the civilized polar opposite of the indigenous New World. ${ }^{131}$ Scientific inquiry was the authority that sought to control these new ecosystems and turn them into resources for the

${ }^{128}$ Shawn William Miller. An Environmental History of Latin America. New Approaches to the America Series. ed. Stuart Schwartz (New York: Cambridge, 2007).

${ }^{129}$ Ross Hassig, Mexico and the Spanish Conquest (New York: Longman, 1994).

${ }^{130}$ Davis, Early Modern Protestantism, 120.

${ }^{131}$ Nancy Leys Stepan, Picturing Tropical Nature (Ithaca: Cornell University, 2001). 
expansion of trade and economies. Furthermore, an ideology of progress in the form of scientific, technological, and material advancement became synonymous with the West's colonization of foreign lands and people. The West's agenda of progress was a linear one that saw Western development as central, and negatively impacted Western perspectives about colonized lands and peoples in order to justify subsuming them into an agenda that meant their own decline and/or decimation.

Historian Warren Dean's book, With Broadax and Firebrand: Destruction of the Brazilian Atlantic Forest explains that during the 17th century the wisdom of indigenous peoples was largely lost to genocide. European diseases including typhus, smallpox, yellow fever, pneumonia, and liver disease decimated estimated millions of indigenous people with each successive wave of colonial migration into the Americas. ${ }^{132}$ In Brazil, many coastal indigenous groups fled deep into the forest to escape the newcomers. Others began to trade information with the colonists regarding survival and extraction of minerals and stones. The Brazilian colonists found that indigenous people were not resilient enough to work as slaves and the Indian became characterized as lazy and meek; these "natives" could, at best, provide some information about how to deal with this new physical environment, but the colonists would use science and technology to advance their ultimate goal of resource extraction.

Portuguese extractive activities included brazilwood in the 17th century, precious stones and minerals in the 18th century, and latex and other Brazilian products used as

${ }^{132}$ See Donald Cooper, Epidemic Disease in Mexico City: 1761-1813 (Austin: University of Texas, 1965); David Noble Cook, Born to Die: Disease and New World Conquest, 1492-1650 (New York: Cambridge Press, 1998); and Sherburne Cook and Woodrow Borah, Essays in Population History: Mexico and the Caribbean (Berkeley: University of California, 1971). 
medicines in the early 19 th century. Brazil became the chief exporter of hard woods, sugar, and coffee in the region in the 18 th century. The development of trade and market economy created a paradox where colonizers were physically and economically dependent on the land they settled and ideologically dependent on the ideals of Europe as the quintessential locus of civilization. The process of Europeanization of Brazil was slow and arduous, perhaps because of the vast expanse and seemingly impenetrable forest or perhaps because the region was one of the last nations to become an independent republic with a political agenda. The Portuguese monarch had not reigned over Brazil with the zeal of the Spanish Crown. Brazil was too large and too lucrative to be amenable to facile control, and Portuguese royalty saw little need to be stern rulers over a land that brought them so much wealth. For example, the 18 th century marked a period where Brazil was fiercely competitive with its sugar and coffee exports, and until the early 1900 s, Brazil had a monopoly over rubber exports.

Missionaries who settled in Brazil to convert the indigenous population described the natives as willing converts. ${ }^{133}$ The European understanding that beings lacking spirituality were not aligned with God shifted from exclusively referring to the natural world to also referring to indigenous people. Alfred Crosby uses an ironic tone to explain that the religious conversion of indigenous people was a twisted form of humanitarian service coupled with prejudice:

Thus it was decided by Rome that the aborigines of America were worthy of conquest and too worthy to be treated as domesticated animals. Again and again during the centuries of European imperialism, the Christian view that all men are brothers was to lead to persecution of non-Europeans- he who is my brother to

${ }^{133}$ Fausto, If God Were a Jaguar, 75. 
the extent that he is unlike me- and to the tempering of imperialism with mercy - he who is my brother deserves brotherly love. ${ }^{134}$

The Gospel was used to validate the negative impact that colonization had on the indigenous population. Some clergy, such as the Jesuit priest, Manoel da Nobrega, the Franciscan friar, Andra Thevet, and the Jesuit Jose de Anchieta were so horrified by what they witnessed that they personally appealed to the Church for laws that would ensure more humane treatment of colonized and enslaved people. ${ }^{135}$ The efforts of the Jesuits to protect indigenous people from slavery led to the expulsion of the religious order from Brazil in 1759. The official protection of natives was enforced through civil, not religious, decree, and that occurred in 1910. This regulation to ensure protection for indigenous people came more than twenty years after the official emancipation of slaves, and it placed them under protection of the state as legal minors.

During the Conquest era, different romanticized images of indigenism began to form. European authors regarded indigenous people as exotic, innocent, and savage. Eighteenth century artist and designer of the Brazilian flag, Jean Baptsiste Debret, sums up the romantic Western notion of the Brazilian indigene here:

[The New World's] age of mysterious and poetic fables will belong to the centuries in which lived the people who we exterminated and who surprised us with their courage, and who invigorate perhaps the nations that came out of the Old World: the memory of their great savagery will overwhelm the soul with pride, their religious beliefs will animate the deserts; their poetic songs, preserved by some [indigenous] nations, will beautify forests. ${ }^{136}$

${ }^{134}$ Alfred W. Crosby, Jr., Columbian Exchange: Biological and Cultural Consequences of $1492,30^{\text {th }}$ Anniversary Edition. (Westport, Praeger, 2003).

${ }^{135}$ Sadler, Brazil Imagined, 29 and 43.

136 Ibid., 136. 
For Debret, indigenous identity is both marvelous and savage, both extinguished and surviving in the forest. The emergence of the noble savage as a "symbol of the nationstate is directly related to the sociopolitical and economic tensions that continued between Portuguese and Brazilians after independence:"137 it communicates that native identity is inferior to European civilization. The process of Brazil gaining independence from Portugal contributed largely to the deprecating tone regarding indigenous identity, which replaced the romantic ideal of the indigenous Brazilian painted by artists.

Now that I have outlined the religious worldview of indigenous Amazonian groups, the Christian tradition as it informs the stewardship model, and the impact of the scientific revolution and Western colonization movements into Brazil, in the next two sections of this chapter I turn to contemporary voices that support or critique Christian foundation of the stewardship model.

\section{Contemporary Christian Ethics}

Contemporary Christian ethicists interpret $\mathrm{k}-\mathrm{b}-\mathrm{sh}$ and $\mathrm{r}-\mathrm{d}-\mathrm{h}$ so that stewardship, not dominion, is foundational in the creation accounts. Michael S. Northcott argues that, "dominion has frequently been misinterpreted as meaning domination and possession. But the Hebrew root of the verb translated as subdue or rule means viceregent or steward and not ruler."138 This reading interprets the divine mandates of human-nature relations with the understanding that God places nature in the care of humans. One might argue that the context of these biblical terms is of a pre-modern time when nature was perceived as threatening; such a nuance to the context of the terms is

${ }^{137}$ Ibid., 133.

${ }^{138}$ Northcott, Christian Ethics, 180. 
cogent considering the relative lack of control humans had over nature. However, it is difficult to dismiss the literal and metaphoric meaning of the Hebrew terms $\mathrm{r}-\mathrm{d}-\mathrm{h}$ and $\mathrm{k}-\mathrm{b}-\mathrm{s}$, and Northcott notes that these terms need to be reinterpreted in light of the spirit of Christian ethics. The quality of this relationship is nuanced by the fact that the "original" role of humans as peaceful, vegetarian gardeners in Eden was disrupted by the Fall. This lapse into sin required a series of covenants between God and humans, including rules of how humans should relate to one another and to nature. In the worldview of many Christian environmental ethicists, the ultimate restoration of total harmony in creation is provided by the resurrection of Christ:

The relational alienation - between God and humanity, between persons, between humans and non-humans, and between non-humans - which issues from the Fall is transformed and redeemed by the restoration of created order which is presaged in the resurrection of Jesus Christ... ${ }^{139}$

Restoration through Jesus has a transcendent, mysterious quality as well as a practical and physical one, meant to embody a miracle of restoration in a broken world order.

Mary Evelyn Jegen focuses on Christ's institution of a community of disciples. Her interpretation of stewardship is based on human fulfillment of God's creation through communion:

Stewardship has failed where it has been reduced to a reasonable way of managing time, talent and treasure .. . The biblical concept of stewardship will become a powerful idea whose time has come when and only when it springs from a contemplative vision that sees God, people and the goods of the earth in a creative and dynamic tension in which the way of union with God and people is precisely through the sharing of the goods we hold in trust. ${ }^{140}$

${ }^{139}$ Ibid., 155.

${ }^{140}$ Mary Evelyn Jegen, "The Church's Role in Healing the Earth," in Tending the Garden: Essays on the Gospel and the Earth, ed. Wesley Granberg-Michaelson (Grand Rapids: William B. Eerdmans, 1987), 102-103. 
Larry Rasmussen agrees with Jegen's emphasis on communal sharing of and fulfillment within creation, but he emphasizes that God's creation is a gift that allows for us to share and witness the wholeness of God's creation reaffirmed in Christ. That Christ communed with all members of society is a powerful message of what is required of humanity. Rasmussen expands this metaphor of healing through community to stewardship over nature:

To love nonhuman life - even inorganic being - as neighbor does not require commonality, unity, or even bonds of affection ... .we should put the welfare and needs of nonhuman others in the same frame of reference as our own welfare and needs. ${ }^{141}$

Michael Northcott also characterizes non-human nature as God's gift to humanity and expression of love. Human gratitude to God for all of the complex and ordered cycles that exist in nature is an essential component of correct faith.

As Northcott points out, these interpretations call for the development of a Christian praxis based on stewardship which has thus far not been central in the Christian tradition, "standard Christian exegesis of the Hebrew Bible has interpreted covenant ... primarily in terms of the dominion of humanity over the creation." ${ }^{142}$ Contemporary Christian ethicists focus on expounding upon corrected readings of scripture in hopes that ideals and society will become aligned. Indeed, their overall interpretations are intended

${ }^{141}$ Larry L. Rasmussen, "Creation, Church, and Christian Responsibility," in Tending the Garden: Essays on the Gospel and the Earth, ed. Wesley GanrbergMichaelson (Grand Rapids: William B. Eerdmans, 1987), 119.

${ }^{142}$ Northcott, Environment and Christian Ethics, 172. 
to clarify the true meaning of religious teaching and to discredit attempts to justify behavior that goes against religious foundations by misusing Scripture.

Northcott helps us identify an enormous issue that exists within Christian traditions, i.e. the difference between doctrine and common understanding. The popular Christian reading of human dominion is derived from a literal reading of a passage such as Gen 1:28, and this reading is informed by the reader's knowledge of Christian doctrine. In most cases, it is not derived using theological analysis or the subsequent myriad of biblical hermeneutic and commentary that Northcott provides. I do not intend to validate Northcott's critique of the Reformation here by insinuating, as he does, that therein lies the basis for the modern ecological crisis. After all, a misunderstood papal encyclical is just as detrimental to the common understanding of human's role vis-à-vis nature as an individualistic reading of the Bible. Northcott falls prey to a common error among Christian environmental ethicists of romanticizing the past. A weakness in Northcott's argument is that he naively assumes that the pre-Reformation concept of self is ideal simply in that it is more collective and communitarian. ${ }^{143}$ Regardless of this point, the majority of Christians without training in biblical hermeneutics and Christian studies are likely unable to understand what the creation accounts say about ethical dealings with nature and the relationship between the creation accounts and the resurrection of Jesus Christ.

Ethicists who base their arguments on the Christian stewardship model seek to reinterpret explicitly hierarchical language in order to soften the decree of dominion. Theirs is the "belief (which can assume religious or secular forms) that human beings 
hold the planetary biosphere as a trust, and are both responsible and answerable for its care, whether to God or to the community of moral agents." ${ }^{144}$ But this reinterpretation of biblical verse using interpretive methods has not affected enough of a paradigmatic shift in society, so the dominant understanding remains aligned with a more literal, traditional reading of the verses. The argument for stewardship continues to be expanded and illustrated in order to debunk its a capitalist, dominion-based use of the environment. Proponents of stewardship stress that the use of nonhuman environment is necessary to the human community but that humans have a responsibility as self-conscious beings to foresee and minimize the damage they inflict on the rest of the environment. Regardless of whether or not "stewardship" can be defended in certain cases as environmentally helpful, the concept of "steward" in terms of the Madeira Complex represents the economic and consumptive use of non-human nature as commodities regardless of their irreplaceability or fragility.

The quality of the role of steward outlined in Hebrew and Christian covenants are such that "human life and society are intricately bound up with the life and community of ecosystems and the biosphere." ${ }^{145}$ The stewardship model holds that responsible care of the biosphere involves ensuring that resources are used in a sustainable way and that human relationships are based on mutuality and sustainability. The term sustainability refers to a system that is "capable of being practiced or maintained indefinitely, regard being had to ecological limits ... they will not undermine other practices or systems that

${ }^{144}$ Attfield, Environmental Ethics, 200.

${ }^{145}$ Northcott, Christian Ethics, 173. 
would otherwise be sustainable." ${ }^{146}$ These aspects of conscientious care and longevity have often been disregarded and transgressed, leading to many critiques and, even, the introduction of alternatives to the stewardship model.

\section{Critiques of Christian Environmental Ethics}

The Hebrew Bible presents a perspective that environmental ethicists call teleological anthropomorphism, that the "whole of creation exists for the sake of humanity." 147 This understanding that humans are above and have dominion over all living things has contributed to an ecological crisis because human needs are placed above associated ecological impact. Val Plumwood explains that teleological anthropomorphism is problematic because it perceives nature as an instrument for human use. She goes on to explain that the fundamental differentiation between nature and humanity, and metaphorically between the body and the spirit, leads to the degradation of former as it benefits the latter. A model of human-earth relations that does not include any intrinsic value for nature risks ecologically devastating acts.

Northcott's critique of the ecological crisis is directed predominately against sinful and unjust human dealings with society and the environment. He characterizes sin and injustice as "modern utilitarian individualism" that rejects the relational quality of all life, human and non-human. ${ }^{148}$ William Dyrness identifies the "complex of disobedience to God, oppression of the poor, and ecological disaster." ${ }^{149}$ Dyrness focuses on the
${ }^{146}$ Attfield, Environmental Ethics, 201.
${ }^{147}$ Attfield, Environmental Ethics, 31.
${ }^{148}$ Northcott, Environment and Christian Ethics, 205-206.
${ }^{149}$ Dyrness, Stewardship of Earth, 60 . 
Hebrew prophets' warnings that the "very stability of the created order is dependent upon Israel's faithfulness to the covenant." 150

In Carolyn Merchant's Reinventing Eden, the metaphor of plenitude, harmony, and, most importantly, partnership is stressed as the basis for correct human and nature relationship. Her reference to Eden has more to do with the audience she directs her argument towards than her methodology; she relies on many religious traditions in order to sketch out her model. Merchant argues that narratives of decline and progress are rooted in the story of Eden and the Fall, and that nature has thus always been read as a part of human "salvation" or damnation rather than on its own terms. Instead of narratives of progress and decline and their reifications of the place of humans as "outside" or "above" the rest of nature, she proposes a model of partnership. A factor that complicates Merchant's model is that nature cannot advocate on behalf of itself and, when humans have to articulate the moral position of nature, their interests will often bias their perspective.

Historically in the West, humans have placed their own needs over those of the rest of nature and the idea that nature has its own moral integrity is still emerging in the field of environmental ethics and this is why Merchant borrows from other worldviews to make her argument. Merchant looks at the relationship that exists between humans and nonhuman nature in terms of moral consideration for both, inclusion of historically marginalized populations and "ecological sound management that is consistent with the

${ }^{150}$ Ibid., 61. 
continued health of both the human and the nonhuman communities." ${ }^{151}$ She notes that humans have the power to create this quality of relationship or to continue decimating nature and narratives such as the biblical accounts reflect the West's perspective that there are limited resources for human use alone. Consequently, Merchant wants to re-envision the Garden of Eden in order to illustrate a relationship of mutuality rather than opposition:

In the new story, both humans hold the apple; the snake is absent. Humans are partners with each other and with nature. Both bear responsibility for their own fate and the fate of nature. This is the story of one possible future for the earth. ... a different ending from that told in Genesis. ${ }^{152}$

In Curse of Cain, Regina Schwartz offers a critique of the legacy of scarcity and violence that has been perpetuated using Scripture. Schwartz would agree with Merchant that a more constructive model for human-nature relations must be based on biblical images of plenitude rather than scarcity. Schwartz is more grounded in biblical exegesis than Merchant, who works instead with an amalgamation of indigenous traditions of kinship with nature and small communitarian activity. However, Schwartz also calls for the biblical narrative to be rewritten. She writes:

My revision would produce an alternative Bible that subverts the dominant vision of violence and scarcity with an ideal of plenitude and its corollary ethical imperative of generosity. It would be a Bible-embracing multiplicity instead of monotheism. ${ }^{153}$

${ }^{151}$ Carolyn Merchant, Reinventing Eden: The Fate of Nature in Western Culture (New York: Routledge, 2003), 224.

${ }^{152}$ Ibid., 242.

${ }^{153}$ Regina Schwartz, Curse of Cain (Chicago: University of Chicago, 1998), 176. 
Schwartz argues that the biblical tradition has been translated in terms of scarcity, which results in violence. She calls for a paradigmatic shift from this to a model based on plenitude. Paradise is a prime biblical example of plenitude, one that precedes prohibitions and competition, "when monotheism is not entangled with scarcity but with an ideal of plenitude, it offers a God who does not set limits but who provides." 154 According to Schwartz, the vision of plenty is distorted by the assumption that plenitude means universalism, because to universalize is to destroy the Other: "sometimes monotheism is entangled with particularism, with the assertion that this God and not any other gods must be worshipped ... The danger of universalism is that totalization will incorporate all difference." ${ }^{155}$ The legacy of violence in the use of the biblical model of human-earth relations is clear in the case of Christian goals of universalism throughout the Conquest era, which decimated millions of indigenous people and permanently altered vast landscapes.

Schwartz's biblical exegesis on the interpretation of the creation and first covenantal agreements is also interesting. She notes that when God promises land, a nation and progeny to Abram (Gen. 13:14-17) the simile of people and dust is made ("I will make your descendants like the dust on the ground ..."). She reminds us that 'adam, the first "earth-creature" is literally (and linguistically) made of soil ('adama), "To be human is to be made of land." 156 Even though Schwartz is critical of the covenantal

${ }^{154}$ Ibid., 35 .

${ }^{155}$ Ibid., 33.

${ }^{156}$ Ibid., 43. 
relationship, which she sees as institutionalizing universalization that then attacks

pluralism, she notes that within the divine bestowal of land in covenants:

God owns the land. It is only leased, with conditions he (sic) stipulates, not bequeathed, to the Israelites. ... Everything about the land- who lives on it, who tills it, whether it is watered, whether it yields fruits- is divinely ordained. ${ }^{157}$ Alternatives to the biblical tradition completely opposed to a model of

stewardship highlight its hierarchical characteristic. Val Plumwood, in Environmental

Culture: The Ecological Crisis of Reason, argues for a "spirituality of place," inspired by native traditions that are focused on the local relationship between humans and nature. ${ }^{158}$ Plumwood is critical of religious traditions that are "hostile to the body, to other species, to the earth, or to women, or that foster racial or religious hatred. . . certain types of 'blood and soil' land spiritualities that form the basis for ethnic exclusion and war." ${ }^{159}$ Likewise, she is critical of universalized spiritualism and of omnipotent forces. In this book, she is explicitly critical of "Christian-rationalist" traditions that place material world below the spirit world. She rejects the Christian tradition that spirit and matter are opposed, and calls for a "better awareness of ourselves as materially embodied beings in a material universe in which we are all material (e.g. food) for one another." ${ }^{160}$

${ }^{157}$ Ibid., 47.

${ }^{158}$ Val Plumwood, Environmental Culture: The Ecological Crisis of Reason (Sterling, VA: Earthscan, 2003), 219.

${ }^{159}$ Ibid.

${ }^{160} \mathrm{Ibid}, 223$. 
The final critique is by Murray Bookchin, who attacks the opposite extreme of anthropocentric models such as deep ecology and proposes an ecological perspective that is both secular and rooted in social context. ${ }^{161}$ Bookchin's dismissal of religious bases for an environmental praxis is based on historical critique:

Historically, a "Self" that absorbs all real existential selves has been used from time immemorial to absorb individual uniqueness and freedom into a supreme "Individual" who heads the state, churches of various sorts, adoring congregations and spellbound constituencies. ${ }^{162}$

He asks "how notions of spirituality can be given priority over the need for a critical evaluation of social structures." 163 The solution that Bookchin derives from an environmental model is based on finding solutions for social problems rather than perpetuating the use of empty rhetoric based on religious concepts. Bookchin admits that his criticisms are harsh and specifically defines social ecology as revolutionary, ecoanarchist, "green," 164 and humanistic (i.e. secular). Bookchin argues that human intellectual and communicative capacities can be used to ameliorate the social problems at the heart of the ecological crisis such as over-population, social domination by profitdriven hegemonies, and associated ecologically devastating practices.

${ }^{161}$ Deep ecology is an environmentalist position coined by Arne Naess in 1973, and later expanded into a full system of human-earth relations by Naess and George Sessions. Its basic principles are that human and non-human life forms have intrinsic value, biodiversity is a value in itself, and that humans should only reduce biodiversity in order to meet their vital needs. They call for changes in policy that reflect biocentric equality, rather than anthropocentric hierarchy. Bill Devall and George Sessions, "Deep Ecology," in Environmental Ethics. ed. Louis P. Pojman (Boston: Wadsworth, 1998), 146-147.

${ }^{162}$ Bookchin, Social Ecology Versus Deep Ecology, 158.

${ }^{163} \mathrm{Ibid}$.

164 This refers to the Green Party. 


\section{CHAPTER III: POST-COLONIAL THEMES}

New understandings beginning in the mid 20th century regarding climatological conditions in the world have led to an environmental perspective that understands humanity and nature as interrelated and interdependent rather than in a dichotomous superior/inferior relationship. Environmental historian Alfred Crosby explains that European settlers had biological and ecological forces, in the form of competitive diseases, weapons, technologies, antibodies, resistant seeds, weeds, and rodents, on their side in order to successfully inhabit the Neo-Americas. ${ }^{165}$ He qualifies this theory by noting that attempts to conquer other areas that had more biologically competitive flora and fauna (including disease) were not as successful. ${ }^{166}$ Ecological colonization in the Amazon today is also characterized by competitive advantage of Western flora and fauna over the native flora and fauna as we see with the competitive advantage that Western epidemics have among demographics, and that genetically engineered monocultures have over native flora and fauna. Crosby convincingly argues that Europeans were not only motivated by Christian zeal and avarice, but also by food shortages at home and the promise of new lands by which to nourish themselves. ${ }^{167}$ The main motivation for capitalist expansion into the Amazon is economic, and the advantage of genetically modified seed, Western pathogens and Western machines provides a competitive advantage over the indigenous people and environment.

${ }^{165}$ See Alfred W. Crosby, Jr., Ecological Imperialism (Westport, Praeger, 2006), and Miller, An Environmental History of Latin America.

${ }^{166}$ Crosby, Ecological Imperialism, 133.

${ }^{167}$ Alfred W. Crosby, Jr., Ecological Imperialism (Westport, Praeger, 2006), 299. 
Alfred Crosby's work on the complex of "exchanges" that took place during the European conquests identifies the effect that unconsidered "goods" such as weeds, rodents, diseases, etc had in the history of European success over indigenous flora and fauna in the Americas. Archives of the first ethnographers in the Americas indicate the European lens of inquiry as well as the vastly "new" cultural formations that existed in these conquered lands. Contemporary studies are unraveling this complex of material exchanges, revealing that much more than precious metals, grain and disease were exchanged between the West and the New World. The work to identify the impact that these exchanges have on non-Western peoples, especially in terms of ideological exchange, is still underway.

Exchanges: Goods and Ideas and the Occident-Amazon Relationship

At the very moment when the native intellectual is anxiously trying to create a cultural work he fails to realize that he is utilizing techniques and language which are borrowed from the stranger in his country. ${ }^{168}$

One aspect of contact between Amazonian indigenous people and the West is exchange of information and of resources. This relationship has two main categories of exchange: goods and ideas. The exchange of goods is discussed above in terms of exchanges of flora and fauna, and is quantifiable information. Identifying the exchange of ideas that occurs between the West and the non-West involves a degree of induction because many indigenous groups do not have written historical sources until contact occurs and Western histories do not include minority viewpoints. Ethnographic data must be critically assessed in order to find the "native" voice and Western histories must be

${ }^{168}$ Frantz Fanon, "On National Culture," in Colonial and Post-Colonial Discourse: A Reader, eds. Patrick Williams and Laura Chrisman (New York: Columbia, 1994), 41. 
seen in terms of their patriarchal and hegemonic biases. The West creates an image of indigenous people and nonhuman nature as primitive, pristine, savage, ignorant, noble, and in need of civilization. The search for an authentic indigenous voice is difficult because indigenous people are using Western concepts and language to formulate their identity as well as marketing their indigenous identity as a political tool to gain visibility. Furthermore, the search for an "authentic" voice serves only to crystallize "native" identity in a place outside of time. In other words, the search for an authentic native identity repeats the old dualism between civilized/primitive rather than acknowledging that native peoples are living, growing, and evolving cultures just like "western culture."

The discussion over whether or not nonhuman nature has a voice and who is best suited to articulate its identity and needs remains unresolved and underrepresented in politics and in Western culture. The West appropriates traditional indigenous discourse in environmental discourse, citing the indigenous people's partnership and reverence of nonhuman nature as essential to reframing the dominant paradigm.

Indigenous identity is formed and used in political and cultural discourses as seen in the indigenous use of the Western concept of stewardship. For example, indigenous Amazonians highlight their invaluable knowledge about the region as a reason to value them in decisions regarding use of rainforest commodities. The present scenario includes an indigenous voice in the debate, one that has emerged since the mid-twentieth century, calling for visibility and upholding of their rights. This is done despite the detriment to their cultural identity, as seen above in the discussion regarding the Mundurucu tribe of Para and their contribution of regional knowledge to the rubber tappers, their way of life was destroyed by their interactions. While the indigenous petition, "Development Yes, 
At Any Cost, No!" ${ }^{169}$ calls for development projects to benefit all citizens, rich and poor, their protest underscores their social needs. Also, by agreeing to development in the region, they undermine their own cultural identity.

The "Indian Issue " in Brazil, which includes issues of land rights, access to social services, and advocacy for visibility and decision-making power does not reflect traditional indigenous needs, which have little to do with planning ahead for future generations, maintaining cultural diversity or requests for Western medicine. Indeed, the "Indian Issue" is formed from the romantic and exploitative lens of the West, which sees indigenous people as the distant forefathers of the nation now ruled by a national agenda of "Order and Progress" and the people who must be treated with care in order to build dams, roads, etc that impact their territory without provoking their dissent and opposition in the matter. ${ }^{170}$ The political and largely rhetorical instances where the "Indigenous Issue" is emphasized reveal that global opinion, the national agenda, and the indigenous voice are all at play in identifying the issues that are now important to Amazonian indigenous groups. The choice between maintaining an "authentic native identity" or being subsumed under the linear notion of the "progress and order" of civilization confronts these communities.

The federal protection agency, FUNAI, is criticized for undermining the rights of indigenous members of national society while claiming to advocate on behalf of the

169 "III Forum permanente dos povos indigenas da amazonia - carta de porto velho- desenvolvimento sim, mas a qualquer custo nao!" COAIB [database on-line]; available from http://www.coiab.com.br/index.php?dest=eixo-3 forum; Internet; accessed 5 January 2009.

${ }^{170}$ Here, I refer specifically to the World Bank "Contribution to the Debate Report," which states that a component of greater facilitation of hydroelectric projects in Brazil includes "careful treatment of indigenous communities" (16). 
indigenous population, which remains legally minor. FUNAI was instituted as a temporary remedy that would assist indigenous communities while they slowly assimilate into the national (i.e. Westernized) culture. When indigenous communities resist their lands being invaded, members of their community are massacred and FUNAI is slow to act on behalf of their legal rights. When members of indigenous society want to study in the nation's capital city, Brasilia, they are prohibited by FUNAI because the agency declares studying abroad anti-cultural. ${ }^{171}$ As the indigenous community increasingly articulates its needs and interests independently of FUNAI, the judiciary status and associated privileges of being indigenous are also undermined. ${ }^{172}$

Ecological Ideology

Distant environmentalists who advocate on behalf of reform regarding land use and treatment of indigenous groups constitute much of "global opinion." The distance seems to cause some degree of disconnect in certain instances. Take, for example, the book Through Amazonian Eyes, which underscores the importance of an ecological ideology:

An ecological ideology is not simply a process of intellectualizing. It represents a guide to action, which reflects the aspirations of those people who try to have their view prevail by any means at their disposal. In small-scale societies such an ideology may be largely consensual, while in nation-states such an ideology more often than not reflects the distribution of power and influence. ${ }^{173}$

${ }^{171}$ Caderno, 20.

${ }^{172}$ Ibid., 21.

${ }^{173}$ Emilio F. Moran, Through Amazonian Eyes: The Human Ecology of Amazonian Populations (Iowa city: University of Iowa Press, 1993), 142. 
In terms of indigenous voice on the Madeira Project, is the genuine indigenous aspiration of autonomy over their lands possible without using the ecological ideology of the greater nation-state, that of stewardship over their territory? Is the ecological ideology of impoverished indigenous communities in Brazil articulated in terms of their "aspirations," or in terms of their struggle to survive? Can the largely uneducated indigenous population of the Amazon distinguish or thoughtfully critique their need for individual and community identity from the "national" identity they hope to be involved in? This lack of knowledge negatively affects their ability to articulate and advocate for their original needs. Lastly, who makes up the oftentimes nebulous "nation-state" and creates their ecological identity, especially in a nation such as Brazil that relies heavily on international financial backing? These questions present us with a complex mélange of groups and identities forging themselves against and in relation to one another.

The most common way to communicate an ideology is through the use of metaphors that symbolize and thus communicate a reality and ethic of action. The ecological ideology of stewardship is based on a metaphor that places humans over and against the rest of the environment. The ideology of sustainable development is largely one of smoke and mirrors used to obfuscate the hegemonic tone inherent in development. If hydroelectric dams are sustainable then why are old dams abandoned to become increasingly less efficient while new dams are built? If hydroelectric development along the Madeira is sustainable then why have scientists agreed that the project will deplete a myriad of natural resources and destroy ecological balance in the region? Ecological models based on stewardship and sustainability are, in this case, continued forms of colonization and biospheric devastation that force different models to conform or die out. 
One cannot assume that a small-scale society can retain an inferior juxtaposed ideology in the face of hegemonic systems such as colonization.

Ecological ideologies that directly refer to the Amazon rainforest address the region by using metaphors that portray the proper way to use its resources from a Western perspective. For example, the "lung of the world" metaphor is used to imply that the Amazonian biosphere must remain preserved in order to maintain the global atmospheric health of the planet. Here, the romantic notion is that the "greenness of the forests as certain evidence of the richness of the habitat" and portrays the biosphere as an untapped paradise. ${ }^{174}$ The scientific foundations of this metaphor are related to the studies that explain how the levels of oxygen generated by the forest offset global warming and $\mathrm{CO} 2$ concentration. There is a recent, twenty-first century, ethical paradigm of globalization and the environment that sees oxygen derived from the Amazon as belonging to the whole world, and calls for the preservation of the Amazon rainforest for the sake of the world, and not for the sake of indigenous people or the maintenance of their traditional lifestyle. The indigenous worldview did not include a vision of their homeland as the "lung of the world" until it received such an image from the nonindigenous global voice.

The metaphor of untapped wilderness is actually an example that may coincide with or counter the "lung of the world" metaphor depending on what line of argument succeeds it. Imagery of an untamed biosphere may be seen in terms of its need of management, development, and demarcation. This metaphor of the Amazon as a wilderness buttresses the argument that the proper course of action is not to leave it

${ }^{174}$ Ibid. 
untapped, but to explore, study, and use it. These three actions on the foreign or native "Other" coincide with a colonizing agenda, which, historically, has been supported by empirical science. However, the metaphor of wilderness is complicated by the scientific imperative that is necessary in order to make use of the wild, but argues that it is a crime to cut down ecosystems that have not been fully measured, quantified, studied and encapsulated in terms of empirical knowledge. The metaphor of taming the wilderness coincides deeply with much of the rhetoric used by big business and government in favor of resource extraction and implantation of agribusiness in the region, but their reliance is more on the science of industry than the botanical science that catalogues species of flora and fauna. The argument that management (i.e. use) of resources is synonymous with all levels of advancement completely ignores the cries of the poor that make it clear resources are not distributed equally in society. The logic of necessary use of resources also supports a recent retort by indigenous constituencies and NGOs that emphasize the preservation of the rainforest so that "natural products" can be extracted gradually and so currently unknown natural compounds can be discovered and synthetically manufactured into profitable products and medicines.

In terms of a traditional indigenous worldview, we find no metaphor to evidence a concern with the future of humanity, nor with the need to know more about or control nature. It is only because of its alignment to environmentalist groups who advocate for indigenous land rights that indigenous voices have articulated a spiritually rooted need to consider the main tenets of the deep ecology movement, which is:

Concerned with future generations rather than just the next few decades, with the Third World rather than just the developed world, with nonhuman species as well as human interests, and with cultural diversity 
rather than uncritical endorsement of the status quo... relations between generations, cultures, countries, and species. ${ }^{175}$

Traditionally, indigenous people of the Amazon were not concerned with these issues because their need to survive in the present was enough. Thus, they constructed mythologies using the past to inform the present. Now indigenous groups insist on their constitutional right to territory while they speak of how their land ecologically belongs to the world through its diversity and uniqueness and must be preserved for generations to come. In their protests against the Madeira Complex, they present themselves as stewards of land that ideologically, if not materially, belongs to the whole world. The rhetoric of being victimized by the West is ineffectual and that is why they are shifting their rhetoric towards a position that argues that they are more suitable stewards and they have trademark rights over the natural compounds being "discovered" by the pharmaceutical industry.

Indigenous Struggle for Rights and the Issue of National Identity

Indigenous individuals in Brazil were legal minors until 1988 and it was their status of "relative legal capacity" which allowed them exclusive use of their lands, as "only legally recognized civil minors can retain their inalienable rights." ${ }^{176}$ The official indigenous right to land shifted from amorphous territory to constitutionally defined only two decades ago. The demarcation of indigenous territory (TI) began in 1961 with the establishment of the Xingu National Park and Reservation in the southwestern Amazon

${ }^{175}$ Attfield, Environmental Ethics, 38-39.

${ }^{176}$ M. Hutchison, et al. "Demarcation and Registration of Indigenous Lands in Brazil," Department of Geodesy and Geomatics Engineering, Technical Report No. 238 (Fredericton, New Brunswick, Canada: University of New Brunswick, 2005), 10. 
region. The concept of demarcated indigenous territory in Brazil is a relatively new one and the former ambiguous understanding of the forest still affects the current debate over how to use forest land properly. The Xingu confront invasions by loggers, miners, soy farmers and cattle herders over four decades after their rights were made official.

The demarcation of indigenous territories and the current legal status of indigenous people have changed their own conception of land in the last forty years, so that they feel entitled to land. This ties into the current concept of indigenous groups identifying themselves as stewards over their territory; they spin this concept of stewardship to justify their right to more land per capita by casting themselves as stewards of spaces that must remain intact for the welfare of the world. In order for indigenous groups to delineate an ethnic discourse on natural resource development on their territories they must work within a Western (non-indigenous) conception of land ownership rather than their own model of itinerant use, not ownership, of land. They have appropriated the concept of territory as a right and now they, too, settle land. They use language that is Western, colonial and even ecological in order to articulate a position regarding these land rights and also use this language to articulate a position on resource development. Their discourse defines their group against and/or in relation to the nation of Brazil, to landless workers, and to the global ecological debate.

The concept of land ownership grows out of this understanding that untapped and unexplored regions of the world need to be assessed and demarcated as private property is also an idea that has been assimilated by indigenous peoples, one more notably per force. Indigenous people did not consider themselves literal owners of the land or limited to the lands they could live on until the Brazilian government "gave" them territories in 
the 20th centuries. In the post-Columbian era, a new stratification of indigenous people emerges: the contacted and the isolated. Some of the indigenous population that survived did so by retreating further into the forest, where settlers could not, or did not dare, go. Others stayed, resisted Western pathogens and began the exchanges necessary in order to survive. 


\section{EPILOGUE}

The model of human stewardship is used in the Madeira Complex to convey the "capitalist-scientific appropriation of nature" as universal and appropriate. This model assumes that nature is at its best when it is managed by human interests and sees these human interests as rights. The Western discourse that humans have the divinely appointed right to use and control the rest of nature is softened by the term "sustainable," which implies that human impacts are not deleterious to the rest of nature and will provide for the interests of future generations. This model assumes that Western . development is the correct course of action to assume, and by centralizing itself as the path towards "progress" and "civilization," it assumes that the only rightful steward is interested in using the rest of nature to benefit humans. Any counterdiscourse is dismissed as irrational, marginal, backwards, or unprofitable. Western appropriation of spaces that teem with nonhuman and indigenous life, such as the Madeira region, is a form of neo-colonization.

Large-scale infrastructural projects such as the Madeira have devastating effects on the environment. These projects attract millions of settlers to indigenous lands, and create a never-ending sense of frontier and material conquest. The call to manage land properly or to generate goods in a sustainable method supposes that careful deliberation over the type and location of development is carried out, but digging beneath the veneer of Environmental Impact Reports such as the one designed for the Madeira Complex reveals that these are short-term profit schemes that benefit a small and elite sector of society. And the claim that development directly impacting isolated and non-isolated indigenous groups is sustainable is untenable in the face of the rate of devastation caused 
by violent confrontations with illegal settlers as well as by the ravages of Western disease on indigenous demographics.

The stewardship model of managing nature in a sustainable way is misused in the case of the Madeira Complex so that profit-driven companies can colonize nature. The protest constituencies, indigenous communities and concerned environmental groups who identify the underestimated ecological and social costs associated with the Madeira Complex form a peripheral counter-discourse which indicates there is a lack of authenticity between the project and the rhetoric used to justify it. However, their cries of protest do not penetrate the centrist nature of the dominant discourse. Thus the peripheral arguments begin to conform to the central position in the debate out of necessity, so that their counter-discourse endures. The indigenous discourse of "rights" creates a means of communicating into the center where decisions are made regarding their existence. This is a forced method of action in the face of a subsuming colonial force that threatens their history and culture, which literally live within the surrounding nonhuman environment.

The colonization of new lands by the West has often involved subsuming indigenous peoples into the category of "nature" and exploiting both for profit and land. The original ecosystemic integrity of the Madeira River and its surrounding basin will be completely altered by the dams, soy farming, and timber extraction. Indigenous groups in the Madeira region of the Amazon will face Western disease, land disputes, and also see their worldview and lifestyle drastically impacted. All the while, the stewardship model and sustainability will be the concepts used to justify the colonization of the Madeira. 
The centrist position demonstrated in the Madeira Complex, which favors largescale development despite environmental and social costs is one that does not allow for a plurality of views concerning human-nature relations. Furthermore, it is an initiative that misuses the Christian stewardship model by placing more emphasis on the order of creation (i.e. human's superiority over the rest of nature) than on the need to care for and sustain all of God's creation. Historically, the misuse of such Christian teachings results in the mistreatment of indigenous people who do not subscribe to a hierarchical model of human-earth relations. 


\section{LIST OF REFERENCES}

"III Forum permanente dos povos indigenas da Amazonia - carta de Porto Velhodesenvolvimento sim, mas a qualquer custo nao!" COAIB Database on-line. Available from http://www.coiab.com.br/index.php?dest=eixo-3 forum.

"Amazonia Lives." The Visual Conscience: Dedicated to Finding Images From Around the World That Speak to Our Conscience. 22 August 2007. Journal on-line. Available from http://thevisualconscience.blogspot.com/2007/08/amazonialives.html.

Attfield, Robin. Environmental Ethics: An Overview for the Twenty-First Century. Malden: Blackwell, 2003.

Bierhorst, John. The Mythology of South America. Oxford: Oxford, 2002.

Boff, Leonardo and Clodovis Boff. Introducing Liberation Theology. Maryknoll: Orbis, 2007.

Bookchin, Murray. "Social Versus Deep Ecology." Environmental Ethics: Readings in Theory and Application. 2nd ed. Louis P. Pojman. Boston: Wadsworth, 1998.

Borges, Beto and Gilles Combrisson. "Indigenous Rights in Brazil: Stagnation to Political Impasse," SAIIC. Database On-line. Available from http://saiic.nativeweb.org/brazil.html.

"Brazil's Sustainable Power Sector Vision 2020- English Summary." World Wildlife Fund. International Rivers Network, 2008. Database On-line. Available from http://www.internationalrivers.org/en/latin-america/amazon-basin/madeirariver/studies-don $\% \mathrm{C} 2 \% \mathrm{~B} 4 \mathrm{t}$-hold-water.

Chaumeil, Jean-Pierre. "Bones, Flutes, and the Dead: Memory and Funerary Treatment in Amazonia." Time and Memory in Indigenous Amazonia: Anthropological Perspectives. eds. Carlos Fausto and Michael Heckenberger. Tallahassee: University Press of Florida, 2007: 243-283.

Cook, David Noble. Born to Die: Disease and New World Conquest, 1492-1650. New York: Cambridge Press, 1998.

Cook, Sherburne and Woodrow Borah. Essays in Population History: Mexico and the Caribbean. Berkeley: University of California, 1971.

Cooper, Donald. Epidemic Disease in Mexico City: 1761-1813. Austin: University of Texas, 1965. 
Crosby, Jr., Alfred W. Columbian Exchange: Biological and Cultural Consequences of 1492. $30^{\text {th }}$ Anniversary Edition. Westport, Praeger, 2003.

Davis, Edward B. and Michael P. Winship. "Early Modern Protestantism." Science and Religion. ed. Gary B. Ferngren. Baltimore: John Hopkins, 2002: 117-129.

Day, Bill. ed. "Our Land." Smiling Zebra Films, 2007. Database On-line. Available from http://www.chicomendes.com/ourlandvideo.html.

Dyrness, William. "Stewardship of the Earth in the Old Testament." Tending the Garden: Essays on the Gospel and the Earth. ed. Wesley Ganrberg-Michaelson. Grand Rapids: William B. Eerdmans, 1987: 50-65.

"Empreendimentos do rio Madeira recebem licença prévia do Ibama." Noticias Ambientais. Journal On-line. Available from http://www.ibama.gov.br/novo ibama/paginas/material.php?id arq $=5401$.

"Environmental Licensing for Hydroelectric Projects in Brazil: A Contribution to the Debate." Brazil Country Management Unit Economic and Sector Work, Latin America and Caribbean Region. Summary Report, 28 March 2008. vol. 1. Database On-line. Available from http://go.worldbank.org/H6SU1Qc800.

Fanon, Fritz. "On National Culture." Colonial and Post-Colonial Discourse: A Reader. eds. Patrick Williams and Laura Chrisman. New York: Columbia, 1994: 3652.

Fausto, Carlos. "If God Were a Jaguar: Cannibalism and Christianity among the Guarani (16th-20th Centuries)." Time and Memory in Indigenous Amazonia:

Anthropological Perspectives. eds. Carlos Fausto and Michael Heckenberger. Tallahassee: University Press of Florida, 2007: 74-105.

"Fórum dos Povos indígenas da Amazônia chega ao fim com protesto contra usinas do Rio Madeira." Rio Madeira Vivo. 1 December 2007. Database On-line. Available from http://www.riomadeiravivo.org.

Gebara, Ivonne. "The Trinity and Human Experience: An Ecofeminist Approach." Women Healing Earth: Third World Women on Ecology, Feminism, and Religion. ed. Rosemary Radford Ruether. Maryknoll: Orbis, 1996.

"God's Earth: A Call for Environmental Stewardship." Films for the Arts and Sciences. Series 7576. Princeton: Films for the Arts and Sciences, 2004.

Hassig, Ross. Mexico and the Spanish Conquest. New York: Longman, 1994. 
Hutchison, M. et al. "Demarcation and Registration of Indigenous Lands in Brazil." Department of Geodesy and Geomatics Engineering. Technical Report. No. 238. Fredericton, New Brunswick, Canada: University of New Brunswick, 2005.

"IIRSA Presentation," IIRSA. Database On-line. Available from http://www.iirsa.org//CD IIRSA/Index.html.

"Indios: direitos históricos." Caderno de Comissão Pro-Índio. 3. Sao Paulo: Comissão Pro-Índio, 1982.

Jegen, Mary Evelyn. "The Church's Role in Healing the Earth." Tending the Garden: Essays on the Gospel and the Earth. ed. Wesley Granberg-Michaelson. Grand Rapids: William B. Eerdmans, 1987.

Johnston, Robert K. "Wisdom Literature and its Contribution to a Biblical Environmental Ethic." Tending the Garden: Essays on the Gospel and the Earth. ed. Wesley Ganrberg-Michaelson. Grand Rapids: William B. Eerdmans, 1987: 66-82.

Kässmann, Margot. "Covenant, Praise and Justice in Creation: Five Bible Studies." Ecotheology: Voices From South and North. ed. David G. Hallman Maryknoll: Orbis, 1994.

Keen, Ralph. The Christian Tradition. Upper Saddle River: Prentice Hall, 2004.

Kinsley, David. "Christianity as Ecologically Harmful." This Sacred Earth: Religion, Nature, Environment. ed. Roger S. Gottlieb. New York: Routledge, 1996: 104-115.

Malinowski, Bronislaw. Magic, Science and Religion and Other Essays. Garden City, NY: Doubleday Anchor, 1954.

McClintock, Anne. "The Angel of Progress." Colonial Discourse and Post-Colonial Theory: A Reader. eds. Patrick Williams and Laura Chrisman. New York: Columbia, 1994: 291-304.

Merchant, Carolyn. Reinventing Eden: The Fate of Nature in Western Culture. New York: Routledge, 2003.

Mindlin, Betty and Surui Indians. Unwritten Stories of the Surui Indians of Rondonia. Cincinnati: Sibylline, 1995.

Moran, Emilio F. Through Amazonian Eyes: The Human Ecology of Amazonian Populations. Iowa City: University of Iowa Press, 1993. 
Murphy, Yolanda and Robert F. Murphy. Women of the Forest. $2^{\text {nd }}$ ed. New York: Columbia University, 1985.

Murphy, Robert F. Headhunter's Heritage: Social and Economic Change Among the Mundurucu Indians. New York: Octagon, 1978.

Murphy, Robert F. "Mundurucú Religion." University of California Publications in American Archaeology and Ethnology. 49. 1 Berkeley: University of California, 1958.

Nisz, Charles. "Madeira's Preliminary License Contributes to Deforestation in Rondonia." Amigos da Terra, Sao Paulo Brasil. 23 October 2007. Journal On-line. Available from http://www.amazonia.org.br/English/noticias/print.cfm?id=254888.

Northcott, Michael S. The Environment and Christian Ethics. New York: Cambridge, 1996.

Ortiz, Lúcia et al. "The Amazon River's Largest Tributary is Under Threat." Friends of the Earth Brazil, et al. trans. Anne Wilson. Database on-line. Available from http://www.foei.org/en/get-involved/take-action/RIO MADEIRA.pdf.

Plumwood, Val. "Decolonizing Relationships with Nature." Decolonizing Nature: Strategies for Conservation in a Post-Colonial Era. eds. William M. Adams and Martin Mulligan. Sterling,VA: Earthscan, 2003: 51-78.

Politis, Gustavo. "Foragers in the Amazon: The Last Survivors or the First to Succeed?" in Unknown Amazon: Culture in Nature in Ancient Brazil. eds. Colin McEwan, Cristiana Barreto and Eduardo Neves. trans. Benjamin Alberti. London: British Museum, 2001: 26-49.

Rasmussen, Larry L. "Creation, Church, and Christian Responsibility." Tending the Garden: Essays on the Gospel and the Earth. ed. Wesley GranbergMichaelson. Grand Rapids: William B. Eerdmans, 1987: 114-132.

"Relatorio de analise do conteudo dos estudos de impacto ambiental (EIA) e do Relatorio de Impacto Ambiental (RIMA) dos aproveitamentos hidroelétricos de Santo Antonio e Jirau, no Rio Madeira, Estado de Rondônia." Ministerio Publico do Estado de Rondonia. 61. Database on-line. Available from http://www.mp.ro.gov.br/web/guest/Interesse-Publico/Hidreletrica-Madeira.

Ribeiro, Berta G. "Ecological Consciousness in Amazonia: The Indigenous Experience." Ecology and Poverty. eds. Leonardo Boff and Virgil Elizondo. Concilium. 5. Maryknoll: Orbis, 1995. 
Sadler, Darlene J. Brazil Imagined: 1500 to the Present. Austin: University of Texas, 2008.

Schüssler-Fiorenza, Elisabeth. In Memory of Her: A Feminist Theological Reconstruction of Christian Origins. New York: Crossroad, 1983.

Schwartz, Regina. Curse of Cain. Chicago: University of Chicago, 1998.

Southgate, Todd. dir. and ed. "Amazon Deforestation (Soy)." Greenpeace, 2005. On-line film. Available from http://vodpod.com/watch/825973-amazondeforestation-soy?pod=iimimiji.

Stepan, Nancy Leys. Picturing Tropical Nature. Ithaca: Cornell University, 2001.

"Studies That Don't Hold Water: 30 Errors in the Environmental Impact Assessment for the Madeira River Hydroelectric Complex." International Rivers Network. 1 January 2007. Database On-line. Available from http://www.internationalrivers.org/en/latin-america/amazon-basin/madeirariver/studies-don $\% \mathrm{C} 2 \% \mathrm{~B} 4 \mathrm{t}$-hold-water.

Switkes, Glenn. "Brazilian Government Moves to Dam Principal Amazon Tributary." Bank Information Center. 12 June 2007. Journal On-line. Available from http://www.bicusa.org/en/Article.10258.aspx.

Switkes, Glenn. "The Amazon Under Threat: Damming the Madeira." International Rivers Network. Database On-line. Available from http://www.irn.org/pubs/factsheets/madeira/MadeiraFact.pdf.

Turner, Terence. "The Sacred as Alienated Consciousness: Ritual and Cosmology Among the Kayapo." Native Religions and Cultures of Central and South America. New York: Continuum, 2002: 278-298.

Viliaça, Aparecida. "Cultural Change as Body Metamorphosis." Time and Memory in Indigenous Amazonia: Anthropological Perspectives. eds. Carlos Fausto and Michael Heckenberger. Tallahassee: University Press of Florida, 2007: 169193.

Holy Bible, New Revised Standard Version with Apocrypha. New York: Oxford University, 1989. 